\title{
Degradation state of organic matter in surface sediments from the Southern Beaufort Sea: a lipid approach
}

\author{
J.-F. Rontani ${ }^{1}$, B. Charriere ${ }^{1}$, M. Petit ${ }^{1}$, F. Vaultier ${ }^{1}$, H. J. Heipieper ${ }^{2}$, H. Link ${ }^{3}$, G. Chaillou ${ }^{4}$, and R. Sempéré ${ }^{1}$ \\ ${ }^{1}$ Aix-Marseille University, Mediterranean Institute of Oceanography (MIO), 13288, Marseille, Cedex 09, Université du Sud \\ Toulon-Var, CNRS-INSU/IRD, UMR6117, UM110, France \\ ${ }^{2}$ Department of Environmental Biotechnology, Helmholtz Centre for Environmental Research - UFZ. Permoserstr. 15 , 04318 \\ Leipzig, Germany \\ ${ }^{3}$ Institut des sciences de la mer de Rimouski, Université du Québec, 310 allée des Ursulines, Rimouski, Québec, Canada \\ ${ }^{4}$ Chaire de Recherche du Canada, Département Biologie, Chimie, Géographie, Université du Québec, 300 allée des Ursulines, \\ Rimouski, Québec, Canada
}

Correspondence to: J.-F. Rontani (jean-francois.rontani@univ-amu.fr)

Received: 14 February 2012 - Published in Biogeosciences Discuss.: 26 March 2012

Revised: 26 July 2012 - Accepted: 26 July 2012 - Published: 5 September 2012

\begin{abstract}
For the next decades significant climatic changes should occur in the Arctic zone. The expected destabilisation of permafrost and its consequences for hydrology and plant cover should increase the input of terrigenous carbon to coastal seas. Consequently, the relative importance of the fluxes of terrestrial and marine organic carbon to the seafloor will likely change, strongly impacting the preservation of organic carbon in Arctic marine sediments. Here, we investigated the lipid content of surface sediments collected on the Mackenzie basin in the Beaufort Sea. Particular attention was given to biotic and abiotic degradation products of sterols and monounsaturated fatty acids. By using sitosterol and campesterol degradation products as tracers of the degradation of terrestrial higher plant inputs and brassicasterol degradation products as tracers of degradation of phytoplanktonic organisms, it could be observed that autoxidation, photooxidation and biodegradation processes act much more intensively on higher plant debris than on phytoplanktonic organisms. Examination of oxidation products of monounsaturated fatty acids showed that photo- and autoxidation processes act more intensively on bacteria than on phytodetritus. Enhanced damages induced by singlet oxygen (transferred from senescent phytoplanktonic cells) in bacteria were attributed to the lack of an adapted antioxidant system in these microorganisms. The strong oxidative stress observed in the sampled sediments resulted in the production of significant amounts of epoxy acids and unusually high proportions of monounsat-
\end{abstract}

urated fatty acids with a trans double bond. The formation of epoxy acids was attributed to peroxygenases (enzymes playing a protective role against the deleterious effects of fatty acid hydroperoxides in vivo), while cis/trans isomerisation was probably induced by thiyl radicals produced during the reaction of thiols with hydroperoxides. Our results confirm the important role played by abiotic oxidative processes in the degradation of marine bacteria and do not support the generally expected refractory character of terrigenous material deposited in deltaic systems.

\section{Introduction}

River-dominated shelves are some of the most important sites of organic carbon (OC) burial in the marine environment (Berner, 1982; Hedges and Keil, 1995). The flux of OC to the sediments of these zones includes autochthonous contributions from primary production in overlying waters as well as allochthonous inputs from terrigenic sources, such as vascular plants, soils and anthropogenic contaminants (Hedges et al., 1997).

The large amounts of terrigenous compounds deposited in deltaic systems are generally considered as being refractory to decomposition due to the presence of protective lignin structures (de Leeuw and Largeau, 1993; Wakeham and Canuel, 2006). However, recent findings have questioned 
this paradigm (Vonk et al., 2008; Van Dongen et al., 2008; Bianchi, 2011). Indeed, several studies demonstrated that terrestrial organic matter $(\mathrm{OM})$ was more degraded in coastal sediments than in river suspended particulate matter (Ingalls et al., 2003; Unger et al., 2005a, b) and that the reactivity of the sedimentary OM is not only influenced by its origin but also by several factors, such as water column depth, redox conditions, microbial activity, mineral composition and sediment physical characteristics (Alkathib et al., 2012; Niggemann et al., 2007; Hedges et al., 1997). Moreover, relatively depleted $\delta^{13} \mathrm{C}$ signatures of bacteria-specific fatty acids were measured in Rhône Prodelta, indicating a preferential utilisation of terrestrial OM by bacteria (Bourgeois et al., 2011). Recently, we studied the degradation of suspended particulate matter (SPM) from the Mackenzie River to the Beaufort Sea by using specific lipid degradation tracers (Rontani et al., 2012a). Lipids of terrestrial vascular plants, which are well preserved in SPM of the Mackenzie River, appeared to be extensively degraded by bacterial and especially autoxidative degradative processes in the water column of the Beaufort Shelf, while planktonic lipids were only weakly affected. A good correlation was observed between the extent of autoxidation and salinity, suggesting that these free radical oxidation processes are enhanced by contact with seawater. In order to explain the specific induction of autoxidative processes on vascular plant-derived material, a mechanism involving metal ion-catalysed homolytic cleavage of photochemically produced hydroperoxides resulting from the senescence of higher plants on land was proposed.

Recent studies predicted that in the next decades significant changes in the Arctic zone will occur (MacGuire et al., 2009; Griffith et al., 2012). These changes should result in a river flow increase coupled with a permafrost thaw and a high coastal erosion modifying the organic and inorganic terrestrial inputs. The longer period of ice-free conditions in summer will modify light availability and thus the primary productivity and photochemical processes affecting both dissolved and particulate OM. Consequently, the relative importance of the fluxes of terrestrial and marine organic carbon to the seafloor will likely change, as will the processing and preservation of organic carbon in Arctic sediments (Katsev et al., 2006). Thus, better knowledge of the degradation processes affecting sedimentary organic matter is essential to establish a baseline to understand the impact of global change in the Arctic Ocean.

To further investigate and confirm our previous results, we examined the lipid content of surface sediments from the Beaufort Shelf. Even though this shelf accounts for only a few percent of the total Arctic Ocean surface area, it receives a large amount of freshwater from the Mackenzie River estimated at $330 \mathrm{~km}^{3} \mathrm{yr}^{-1}$ (Stein and Macdonald, 2004). This flux contributes vast quantities of terrigeneous organic carbon to Beaufort Sea (O'Brien et al., 2006).

Using specific lipid degradation products from $\Delta^{5}$-sterols and monounsaturated fatty acids that have been proposed for distinguishing biotic from abiotic processes, and photooxidation from autoxidation (Christodoulou et al., 2009; Rontani et al., 2009, 2011), we evaluated the roles played by heterotrophic, photodegradative, and autoxidative processes in the degradation of the main components of OM (higher plants, micro-algae and bacteria).

\section{Material and methods}

\subsection{Study area}

This study was conducted in the southeast Beaufort Sea, with an emphasis on the MacKenzie delta outflow, during summer 2009 on board the Canadian research icebreaker CCGS Amundsen as a part of the international Malina Program. The physical, biological and sedimentological characteristics of Malina study area are described in more details in Babin et al. (2012).

The Mackenzie Shelf is a coastal region of the Beaufort Sea located along the Arctic Ocean's Canadian coast, between Point Barrow in northern Alaska and the western part of the Canadian Arctic Archipelago. The area is dominated by a $\sim 100 \mathrm{~km}$ wide shelf that covers an area of $64000 \mathrm{~km}^{2}$ (to the isobath $200 \mathrm{~m}$ ) which is relatively small compared to the broad Eurasian Shelf (Stein and Macdonald, 2004; O'Brien et al., 2006). The shelf is bordered on the west by the Mackenzie Trough and on the east by Amundsen Gulf. The major input of sediment and particulate organic carbon to this area comes from the Mackenzie River (O'Brien et al., 2006). The Mackenzie is the largest river draining into the Arctic Ocean in sediment and particulate organic carbon supply $\left(127 \times 10^{6}\right.$ tons $\mathrm{yr}^{-1}$ of sediment and $2.1 \times 10^{6}$ tons $\mathrm{yr}^{-1}$ of particulate organic carbon respectively, Macdonald et al., 1998; Holmes et al., 2002) and the fourth largest in terms of freshwater discharge $\left(3.3 \times 10^{11} \mathrm{~m}^{3} \mathrm{yr}^{-1}\right.$, Milliman and Meade, 1983; Brunskill, 1986; Macdonald et al., 1998). Despite the coastal erosion may be locally important, particularly in the inner shelf, the contribution of the MacKenzie River is clearly much more important $\left(5.6 \times 10^{6} \mathrm{ta}^{-1}\right.$ vs. $64.45 \times 10^{6} \mathrm{ta}^{-1}$; Hill et al., 1991; MacDonald et al., 1998; Rachold et al., 2000) and supplies about 95-99\% of the sediment to the Beaufort Shelf (Rachold et al., 2004).

The shelf is seasonally ice covered. The sea ice usually starts to form in October and reaches its maximum $2 \mathrm{~m}$ thickness in March. The landfast ice covers the inner shelf $(<20 \mathrm{~m}$ water depth). It is bounded offshore by an hummock, or "stamucki", formed by the collision of the mobile offshore ice pack and the landfast ice edge. In winter, the stamucki retains the turbidity waters from the MacKenzie River under the landfast ice to the inner shelf. Sporadic polynya form at the edge of the landfast ice due to winter winds that push mobile ice pack away from the stamucki. Around June, the stamucki breaks and releases the Mackenzie River plume in the top $10 \mathrm{~m}$ of the surface layer of the MacKenzie Shelf. 
This plume is pushed seaward by easterly winds (MacDonald and $\mathrm{Yu}, 2006)$. The sea ice break-up favors the formation of polynya and then marine organic matter production.

Primary productivity over the Mackenzie Delta/Beaufort Shelf is about $3.3 \times 10^{6}$ tons $\mathrm{yr}^{-1}$ of particulate organic carbon during late spring and summer (Macdonald et al., 1998). Production by ice algae accounts for less than $10 \%$ of the marine production in this area (Horner and Schrader, 1982).

Sediments of the Beaufort shelf are characterized by high silt and clay content and very low sand content (Hill et al., 1991; Conlan et al., 2008). It is generally considered that the particulate organic carbon derived from primary production is rapidly recycled in the water column and/or at the sediment interface (Magen et al., 2010), while a large fraction of land-derived particulate organic carbon (50-60\%) accumulate in shelf and slope sediments (Macdonald et al., 1998). The sedimentation rates vary from 0.040 to $0.12 \mathrm{~cm} \mathrm{yr}^{-1}$ in the Mackenzie Canyon axis (Richerol et al., 2008) and is around $0.13 \mathrm{~cm} \mathrm{yr}^{-1}$ at stations located in the deepest area of the Mackenzie Shelf (isobaths $200 \mathrm{~m}$ depth; Scott et al., 2009; Bringué and Rochon, 2012). In shallow sediments of the shelf, seasonal landfast ice can scour the sediment to water depths of 15 to $\sim 50 \mathrm{~m}$ (Blasco et al., 1998). This frequently resuspends and exports material to the slope and deep Arctic basins.

\subsection{Sediment sampling}

Samples were collected from the MacKenzie Shelf and Slope at eight sites ranging in water depths from $45 \mathrm{~m}$ to $580 \mathrm{~m}$ in August 2009 onboard the icebreaker CCGS Amundsen (Fig. 1). At each sampling station, an USNEL box corer $(50 \times 50 \times 40 \mathrm{~cm})$ was deployed for collecting seafloor sediments. Water overlying the box core sediments was drained with a silicone tube. From each box core, one sample of ca. $50 \mathrm{~cm}^{2}$ was collected from intact sediment surface $(0$ to $1 \mathrm{~cm}$ ) (integrating 7 to $25 \mathrm{yr}$ of sedimentation) and frozen immediately at $-80^{\circ} \mathrm{C}$ for later analysis.

\subsection{Treatment of the samples}

Each frozen sediment sample was extracted four times with $\mathrm{CHCl}_{3}-\mathrm{MeOH}-\mathrm{H}_{2} \mathrm{O}(1: 2: 0.8, v / v / v, 3 \times)$ using ultrasonication for $15 \mathrm{~min}$ (separation of sediment and solvents by centrifugation at $3500 \mathrm{rpm}$ for $9 \mathrm{~min}$ ). To initiate phase separation after ultrasonication, $\mathrm{CHCl}_{3}$ and purified $\mathrm{H}_{2} \mathrm{O}$ were added to the combined extracts to give a final volume ratio of $1: 1: 0.9(v / v / v)$. The upper aqueous phase was extracted twice with $\mathrm{CHCl}_{3}$ and the combined $\mathrm{CHCl}_{3}$ extracts were dried over anhydrous $\mathrm{Na}_{2} \mathrm{SO}_{4}$, filtered and the solvent removed via rotary evaporation.

The residues thus obtained were then reduced with excess $\mathrm{NaBH}_{4}(70 \mathrm{mg})$ at room temperature in $\mathrm{MeOH}(25 \mathrm{ml}$; $30 \mathrm{~min}$ ). This was carried out to reduce labile hydroperoxides (resulting from photo- and autoxidation) to alcohols which

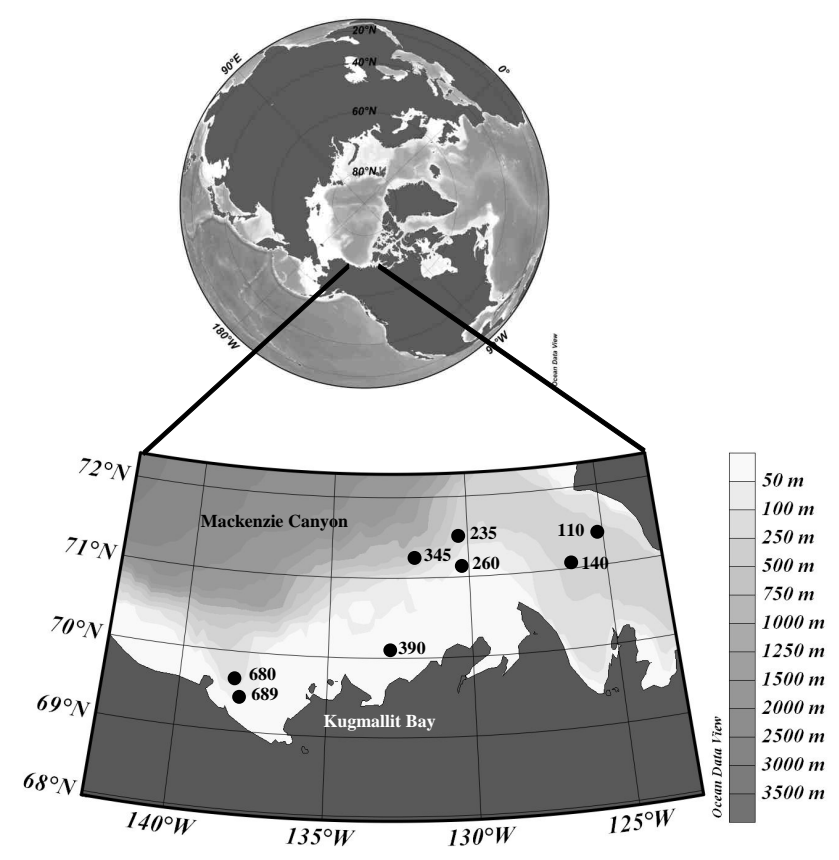

Fig. 1. Map of the studied area with locations of the different stations investigated.

were more amenable to analysis using Gas Chromatography/Electron impact Mass spectrometry (GC-EIMS). During this treatment, ketones are also reduced and the possibility of some ester cleavage cannot be excluded. It is well known that metal ions can promote autoxidation during hot saponification procedures. The prior reduction of hydroperoxides with $\mathrm{NaBH}_{4}$ allowed us to avoid such autoxidative artifacts during the alkaline hydrolysis. After $\mathrm{NaBH}_{4}$ reduction, water $(25 \mathrm{ml})$ and $\mathrm{KOH}(2.8 \mathrm{~g})$ were added and the resulting mixtures saponified by refluxing $(2 \mathrm{~h})$. After cooling, the contents were acidified (dilute $\mathrm{HCl}, 2 \mathrm{~N}$ ) to $\mathrm{pH} 1$ and extracted with dichloromethane (DCM, $3 \times 10 \mathrm{ml})$. The combined DCM extracts were dried over anhydrous $\mathrm{Na}_{2} \mathrm{SO}_{4}$, filtered and concentrated by way of rotary evaporation at $40^{\circ} \mathrm{C}$ to give the total lipid extract (TLE).

\subsection{Osmium tetroxide oxidation}

A fraction of TLE and $\mathrm{OsO}_{4}(1: 2, w: w)$ were added to a pyridine-dioxane mixture $(1: 8, v / v, 5 \mathrm{ml})$ and incubated for $1 \mathrm{~h}$ at room temperature. Then, $6 \mathrm{ml}$ of $\mathrm{Na}_{2} \mathrm{SO}_{3}$ suspension $\left(16 \% \mathrm{Na}_{2} \mathrm{SO}_{3}\right.$ in water-methanol, $\left.8.5: 2.5, v / v\right)$ was added and the mixture was again incubated for $1.5 \mathrm{~h}$. The resulting mixture was gently acidified $(\mathrm{pH} 3)$ with $\mathrm{HCl}$ and extracted three times with DCM $(5 \mathrm{ml})$. The combined DCM extracts were subsequently dried over anhydrous $\mathrm{Na}_{2} \mathrm{SO}_{4}$, filtered and concentrated. 


\subsection{Silylation}

After evaporation of solvent, residues were taken up in $300 \mu \mathrm{l}$ of a $2: 1(\mathrm{v} / \mathrm{v})$ mixture of pyridine and pure bis(trimethylsilyl)trifluoroacetamide (BSTFA; Supelco) and silylated at $50^{\circ} \mathrm{C}$ for $1 \mathrm{~h}$. The solution was re-evaporated to dryness under a stream of $\mathrm{N}_{2}$ and the derivatized residue was taken up in a mixture of EtOAc and BSTFA (to avoid desilylation of the more easily silylated compounds) for GC-EIMS analysis. It may be noted that derivatisation of stera$3 \beta, 5 \alpha, 6 \beta$-triols with pyridine/BSTFA results in the silylation of only the positions 3 and 6 . The use of more powerful silylating reagents, such as Trimethylsilylimidazole/N,OBis(trimethylsilyl)acetamide/Trimethylchlorosilane (Bortolomeazzi et al., 1999) or BSTFA/Dimethylsulfoxide (C. Aubert, unpublished results), yields complete silylation of $3 \beta, 5 \alpha$-dihydroxysterols. Unfortunately, the presence of an additional (easily silylated) $6 \beta$-hydroxyl group in steran- $3 \beta, 5 \alpha, 6 \beta$-triol molecules induces a supplementary steric hindering, which precludes silylation at the 5 position.

\subsection{GC-EIMS}

Compounds were identified by comparison of retention times and mass spectra with those of standards and quantified (calibration with external standards) by GC-EIMS. For low concentrations, or in the case of co-elutions, quantification was achieved using selected ion monitoring (SIM). The main characteristic mass fragment ions used to quantify degradation products of sterols and monounsaturated fatty acids were previously described (Marchand and Rontani, 2001; Christodoulou et al., 2009; Rontani et al., 2009). Standard oxidation products of palmitoleic, oleic and vaccenic acids and sterols were obtained according to previously described procedures (Rontani and Marchand, 2000; Marchand and Rontani, 2001).

Due to their only partial silylation, steran- $3 \beta, 5 \alpha, 6 \beta$-triols need to be analysed with great care. The use of hot splitless injectors (which can discriminate against high-boiling compounds and induce thermal degradation) should be avoided. The best results were obtained with an on-column injector coupled to a deactivated retention gap.

GC-EIMS analyses were carried out with an Agilent 6890 gas chromatograph connected to an Agilent 5973 inert mass spectrometer. The following conditions were employed: $30 \mathrm{~m} \times 0.25 \mathrm{~mm}$ (i.d.) fused silica column coated with HP-1-MS (Agilent; $0.25 \mu \mathrm{m}$ film thickness); oven temperature programmed in three sequential steps: (i) $70^{\circ} \mathrm{C}$ to $130^{\circ} \mathrm{C}$ at $20^{\circ} \mathrm{C} \mathrm{min}{ }^{-1}$; (ii) $130^{\circ} \mathrm{C}$ to $250^{\circ} \mathrm{C}$ at $5^{\circ} \mathrm{C} \mathrm{min}^{-1}$; and (iii) $250^{\circ} \mathrm{C}$ to $300^{\circ} \mathrm{C}$ at $3{ }^{\circ} \mathrm{C} \mathrm{min}{ }^{-1}$; carrier gas (He) maintained at 0.69 bar until the end of the temperature program and then programmed from 0.69 bar to 1.49 bar at 0.04 bar $\min ^{-1}$; injector (on column with retention gap) temperature $50^{\circ} \mathrm{C}$; electron energy $70 \mathrm{eV}$; source temperature $190^{\circ} \mathrm{C}$; cycle time 1.99 and 8.3 cycles s $^{-1}$ in SCAN and SIM modes, respectively.

\subsection{Choice of $\Delta^{5}$-sterol degradation tracers and estimation of photooxidation, autoxidation and biodegradation}

The relative importance of biodegradation, photooxidation, and autoxidation for different components of sediments was estimated by quantifying specific degradation products of three "model" $\Delta^{5}$-sterols: 24 -methylcholest-5,22Edien-3 $\beta$-ol (brassicasterol) (indicative of phytoplanktonic sources, Volkman, 1986, 2003), 24-methylcholest-5-en-3 $\beta$ ol (campesterol), and 24-ethylcholest-5-en-3 $\beta$-ol (sitosterol) (both indicative of terrestrial higher plant source in the zone considered, Goñi et al., 2000). Stera- $3 \beta, 5 \alpha, 6 \beta$-triols, $\Delta^{4}$ stera- $3 \beta, 6 \alpha / \beta$-diols and $5 \alpha(\mathrm{H})$-stan- $3 \beta$-ols were selected as specific tracers of autoxidative, photooxidative and biological degradation processes, respectively (Rontani et al., 2009; Christodoulou et al., 2009; Fig. 2).

Autoxidation of $\Delta^{5}$-sterols mainly affords non-specific and unstable $\Delta^{5}-7 \alpha / 7 \beta$-hydroperoxides and to a lesser extent 5,6-epoxysterols and stera- $3 \beta, 5 \alpha, 6 \beta$-triols; the epoxides being converted to the corresponding triol during the treatment (Christodoulou et al., 2009). On the basis of their high specificity and stability, stera- $3 \beta, 5 \alpha, 6 \beta$-triols were selected as tracers of autoxidative processes (Fig. 2) and autoxidation percentage was estimated with the following equation: autoxidation $\%=($ stera- $3 \beta, 5 \alpha, 6 \beta$-triol $\% \times 2.4)$ on the basis of the results of different incubation experiments (Rontani et al., 2012a) and autoxidation rate constants previously calculated by Morrissey and Kiely (2006).

Type II (i.e. singlet oxygen mediated) photooxidation of $\Delta^{5}$-sterols produces mainly unstable $\Delta^{6}-5 \alpha$-hydroperoxides with low amounts of $\Delta^{4}-6 \alpha / 6 \beta$-hydroperoxides (Smith, 1981). $\Delta^{4}-6 \alpha / 6 \beta$-hydroperoxides were selected as tracers of photooxidation of $\Delta^{5-}$-sterols (Fig. 2) due to their high specificity and relative stability (Rontani et al., 2009; Christodoulou et al., 2009). These compounds were quantified after $\mathrm{NaBH}_{4}$ reduction to the corresponding diols and photooxidation percentage was obtained from the equation: photooxidation $\%=\left(\Delta^{4}\right.$-stera- $3 \beta, 6 \alpha / \beta$-diols $\% \times(1+$ $0.3) / 0.3$ ) (Christodoulou et al., 2009) based on the ratio $\Delta^{4}$ $6 \alpha / 6 \beta$-hydroperoxides / $\Delta^{6}-5 \alpha$-hydroperoxides measured in biological membranes (0.30) (Korytowski et al., 1992).

Although complete mineralisation of $\Delta^{5}$-sterols may be achieved in the marine environment by bacteria belonging to several genera, these compounds can also undergo aerobic bacterial hydrogenation leading mainly to ster-4-en3-ones, $5 \alpha(\mathrm{H})$-stanones and $5 \alpha(\mathrm{H})$-stanols (de Leeuw and Baas, 1986; Wakeham, 1989). $5 \alpha(\mathrm{H})$-stanols, which are also produced by $\mathrm{NaBH}_{4}$-reduction of the corresponding stanone during the treatment, were selected as specific tracers of $\Delta^{5}$ sterol biodegradation (Fig. 2). 

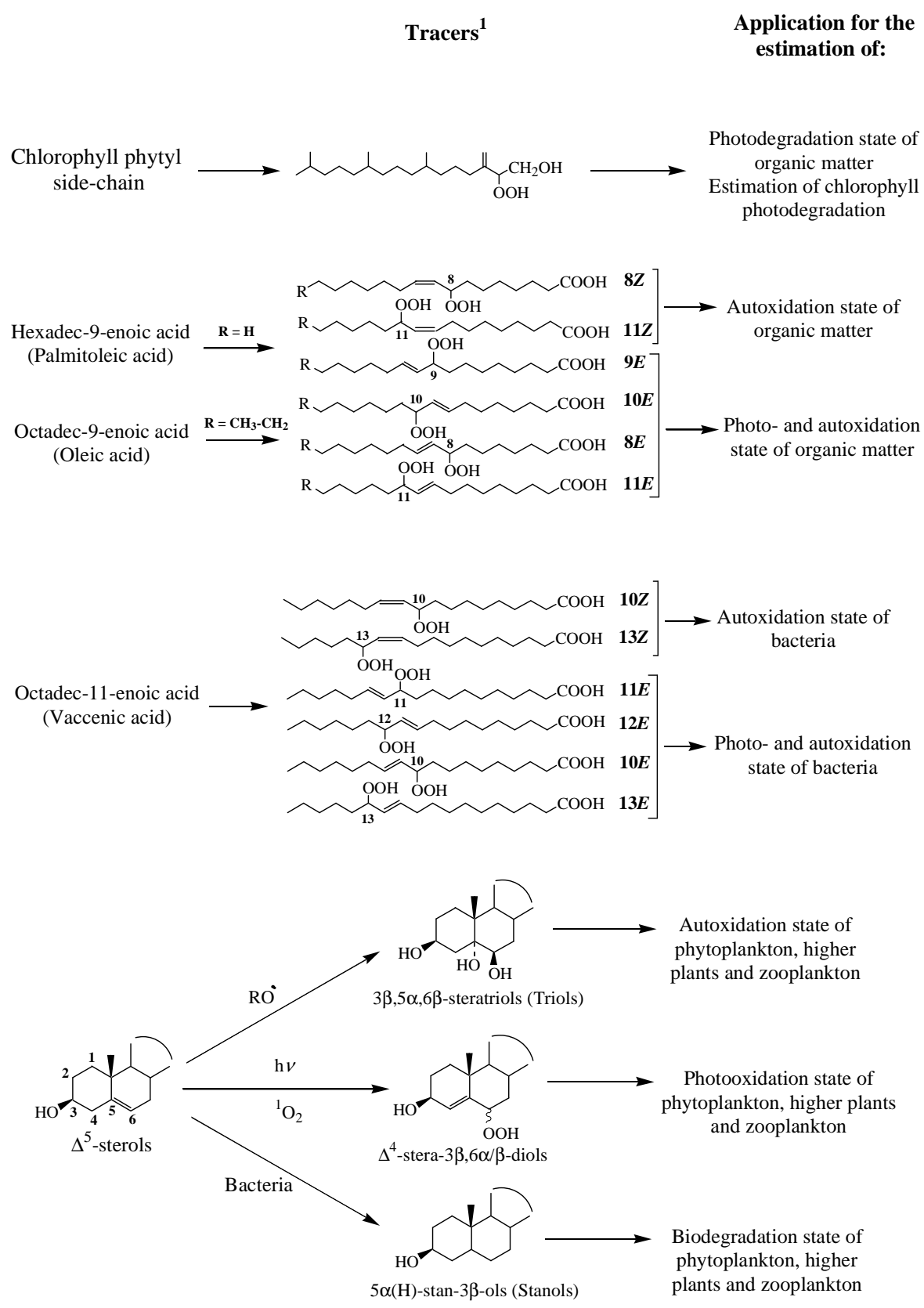

Fig. 2. Formulae and potential applications of the different lipid tracers of degradation processes employed in the present work. ${ }^{1}$ Quantified after $\mathrm{NaBH}_{4}$-reduction to the corresponding alcohols and subsequent silylation.

\subsection{Choice of fatty acid degradation tracers and estimation of photooxidation and autoxidation}

The reactivity of unsaturated fatty acids relative to auto- and photooxidative processes logically increases with the number of double bonds (Frankel, 1998; Rontani et al., 1998). Oxidation products of polyunsaturated fatty acids (PUFA) are thus considered as very sensitive tracers of these processes. Unfortunately, they are too labile to be used for this purpose. In contrast, autoxidation and photooxidation products of mo- nounsaturated fatty acids, although produced much more slowly, are stable enough in the environment to act as markers of these processes (Marchand and Rontani, 2001, 2003; Marchand et al., 2005; Rontani et al., 2011).

Singlet oxygen $\left({ }^{1} \mathrm{O}_{2}\right)$-mediated photooxidation of monounsaturated fatty acids involves a direct reaction of " ${ }^{1} \mathrm{O}_{2}$ with the carbon-carbon double bond by a concerted "ene" addition (Frimer, 1979) and leads to formation of hydroperoxides at each carbon of the original double bond with an allylic trans-double bond, which can subsequently undergo 
highly stereoselective radical allylic rearrangement (Porter et al., 1995; Fig. 2). In contrast, free radical oxidation of monounsaturated fatty acids produces six isomeric hydroperoxyacids (Frankel, 1998; Fig. 2). Autoxidative processes can be easily characterised based on the presence of cis allylic hydroperoxyacids, which are specific products of these degradation processes (Porter et al., 1995; Frankel, 1998). In order to evaluate autoxidation, we needed to calculate (after $\mathrm{NaBH}_{4}$-reduction of hydroperoxides to the corresponding alcohols) the amounts of the four trans-hydroxyacids arising from autoxidation according to the proportions of the two cis-hydroxyacids observed (Frankel, 1998; Marchand and Rontani 2001; Fig. 2) and the ambient seawater temperature $\left(-1{ }^{\circ} \mathrm{C}\right)$. The temperature of oxidation has a significant effect on the cis and trans configuration of the initial hydroperoxides formed (Frankel, 1998). For this purpose, we employed different equations previously proposed by Marchand and Rontani (2001). Photooxidation was estimated from transhydroxyacids (after subtraction of the amounts of these compounds arising from autoxidation processes).

We thus quantified the products of both autoxidation and photooxidation of hexadec-9(cis)-enoic (palmitoleic), octadec-9(cis)-enoic (oleic) and octadec-11(cis)enoic (vaccenic) acids, which were the three dominant monounsaturated fatty acids in the different sediment samples investigated. Oleic and palmitoleic acids have diverse possible biological sources (plants, fungi, yeasts, bacteria, animals or algae) (Harwood and Russell, 1984), thus their oxidation products may only be used to assess abiotic degradation of bulk OM of sediments. In contrast, oxidation products of vaccenic acid, which is a typical biomarker for Gramnegative bacteria (Sicre et al., 1988, Keweloh and Heipieper, 1996), are very useful to estimate the extent of sedimentary bacteria degradation.

\section{Results and discussion}

\subsection{Biotic and abiotic alteration of $\Delta^{5}$-sterols}

Sterol composition of the different sediments sampled appeared to be dominated by cholesterol and sitosterol. Lesser amounts of campesterol, brassicasterol, 24-methylcholest5,24(28)-dien-3 $\beta$-ol (24-methylenecholesterol) and 24ethylcholest-5,22E-dien-3 $\beta$-ol (stigmasterol) could be also detected (Table 1). Similar sterols were previously identified by Belicka et al. (2004) in the top layer $(0-2 \mathrm{~cm})$ of sediments from the Beaufort Sea. The lowest abundance of cholesterol observed by these authors in sediments collected near to the stations 235, 260 and 345 may be attributed to a progressive degradation of zooplanktonic faecal material, which contributes significantly to the sinking particles of this zone and contains a high proportion of cholesterol (Rontani et al., 2012b), deeper in the sediment in the second $\mathrm{cm}$ of sediments. This assumption is supported by the penetration depth of oxygen, which may reach $2-4 \mathrm{~cm}$ in this zone (Magen, 2007) and which may contribute to oxic degradation of the settled organic matter well deeper than the sediment-water interface.

Degradation tracers of brassicasterol, sitosterol and campesterol, which could be identified in all investigated sediments (see example for sitosterol in Fig. 3), were quantified. The results obtained are summarized in Fig. 4. The three sterols exhibited well distinct degradation states, with the following order of reactivity: sitosterol $>$ campesterol $\gg$ brassicasterol. It is interesting to note that Yunker et al. (2005) previously also reported a faster removal rate relative to organic carbon of campesterol and sitosterol than of brassicasterol in sediment cores from the Beaufort and Chukchi seas and Canuel and Martens (1996) observed a faster degradation rate for sitosterol than brassicasterol in nearshore sediments from North Carolina. Brassicasterol (mainly arising from marine and freshwater phytoplankton, Volkman, 1986, 2003; Fahl et al., 2003) appeared to be very weakly affected by biotic and abiotic degradation processes in Beaufort Shelf sediments (Fig. 4). In contrast, autoxidation, photooxidation and biodegradation processes acted significantly on sitosterol and campesterol (mainly arising from terrestrial higher plants). Goñi et al. (2000) previously estimated terrigenous contribution for these two sterols in sediments of the same zone and found approximately $60 \%$ for campesterol and $70 \%$ for sitosterol. This lowest contribution of terrigenous material to campesterol was also outlined by Yunker et al. (1995, 2005). The reduced degradation observed in the case of campesterol (Fig. 4) may be thus attributed to a significant contribution of weakly altered Chlorophytes or Prasinophytes micro-algae containing high proportions of campesterol (Volkman, 1986) and present in summer in this zone (Hill et al., 2005), to this sterol.

It was previously observed that autoxidation processes play a key role in the degradation of terrestrial suspended POM in the Beaufort Sea (Rontani et al., 2012a). Although this seems to be also the case for particles accumulating at the seafloor, the proportions of autoxidation products (ranging from 20 to $120 \%$ of the residual parent sitosterol; Fig. 4) are practically one order of magnitude lower than those previously observed in suspended particles collected in the same zone. These differences may be attributed to the fact that suspended particles, which spend a very long time in the water column (where autoxidation strongly occurs) generally only weakly contribute (after aggregation) to the sedimentary record (Wakeham and Lee, 1989). Lateral transport of sediments that already have known degradation and diagenetic processes could be another explanation. Indeed, in this case sediment would consist in part of particles that have settled closer to land and have thus spent less time in water column where degradation is more efficient.

Relatively high proportions of Type II photooxidation products of campesterol and sitosterol (e.g. $60 \%$ of the residual parent sitosterol at station 680, for example; Fig. 4) were 
Table 1. Sterols content $\left(\mu \mathrm{g} \mathrm{g}^{-1}\right)$ of the sediments investigated.

\begin{tabular}{lrrrrrrrr}
\hline Sterols & 110 & 140 & 235 & 260 & 345 & 390 & 680 & 689 \\
\hline Cholesterol & 9.3 & 3.9 & 1.5 & 31.6 & 1.8 & 2.0 & 1.5 & 4.6 \\
Brassicasterol & 3.0 & 2.2 & 0.3 & 17.4 & 0.3 & 1.0 & 0.5 & 1.6 \\
24-Methylenecholesterol & 1.5 & 0.8 & 0.1 & 8.2 & 0.1 & 0.4 & 0.3 & 0.6 \\
Campesterol & 1.1 & 0.6 & 0.1 & 5.8 & 0.1 & 0.5 & 0.4 & 1.1 \\
Stigmastérol & 1.3 & 0.3 & 0.1 & 3.3 & 0.1 & 0.3 & 0.2 & 0.4 \\
Sitosterol & 6.2 & 1.4 & 0.4 & 13.9 & 0.5 & 0.8 & 1.1 & 1.9 \\
\hline
\end{tabular}

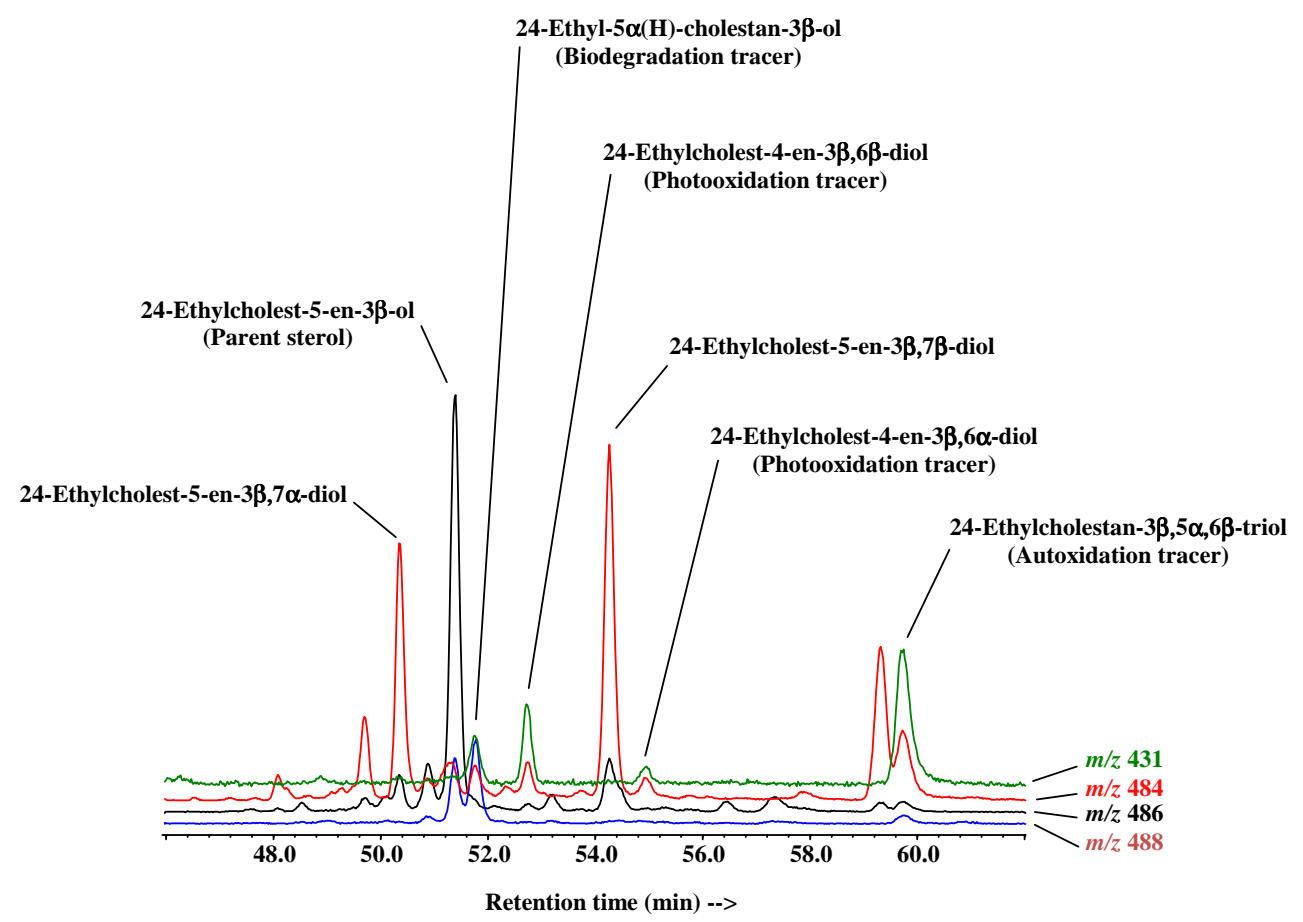

Fig. 3. Partial $\mathrm{m} / \mathrm{z}$ 486, 488, 484 and 431 ion chromatograms showing presence of sitosterol degradation products in the total lipid extract of surface sediments $(0-1 \mathrm{~cm})$ collected at the station 680 .

detected in the different samples. These results contrast with the very weak amounts of photooxidation products of these sterols previously observed in suspended POM (for example $10 \%$ of the residual parent sitosterol at the same station 680; Rontani et al., 2012a). Due to the involvement of very intensive autoxidation processes in these suspended particles, a free radical driven breakdown of photochemicallyproduced hydroperoxides might likely explain their unexpected very weak content of sterol photodegradation products. These findings support the idea that suspended and sinking particles that reach the seafloor have distinct origins and then distinct degradation pathways during their transit.

\subsection{Biotic and abiotic alteration of monounsaturated fatty acids}

Linear fatty acids ranging from $\mathrm{C}_{14}$ to $\mathrm{C}_{18}$ have been detected in the different samples investigated (Table 2). The lack of long-chain $\left(\mathrm{C}_{20}-\mathrm{C}_{28}\right)$ fatty acids, which are characteristic of epicuticular waxes of terrestrial higher plants (Kolattukudy, 1976; Gagosian et al., 1987), was attributed to bacterial degradation processes, which act intensively on terrestrial material in the mixing zone of the Mackenzie (Rontani et al., 2012). Degradation products of the main monounsaturated fatty acids present in these sediments, i.e. palmitoleic, oleic and vaccenic acids, were quantified. The results obtained are summarized in Figs. 5a (vaccenic acid), 6a (oleic acid) and 7a (palmitoleic acid). The three selected monounsaturated fatty acids exhibited well distinct abiotic degradation states. Photooxidation processes appeared to act more intensively in bacteria (Fig. 5a) than in other organisms (Figs. 6a and 7a). This observation is in good agreement with the highest photoreactivity of vaccenic acid (relative to oleic and palmitoleic acids) previously observed by Christodoulou et al. (2010) during irradiation of non-axenic 
$\mathbf{A}$

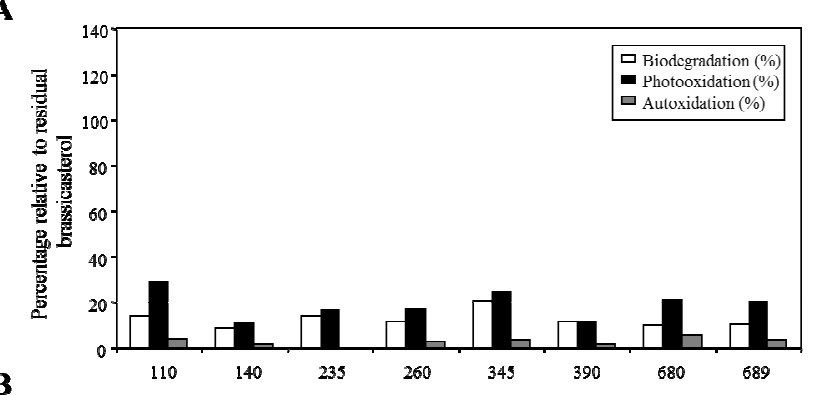

B

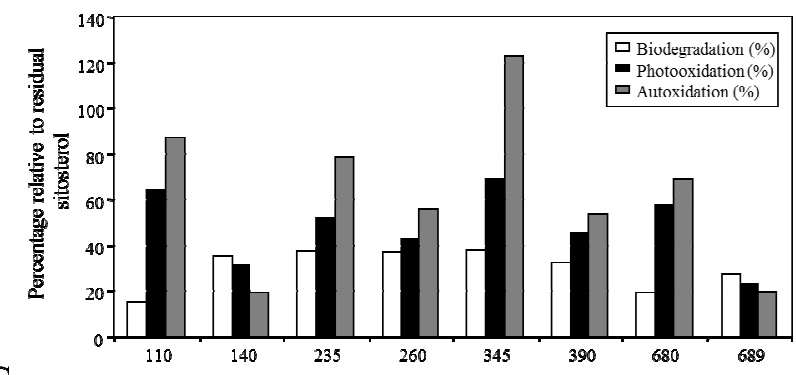

$\mathbf{C}$

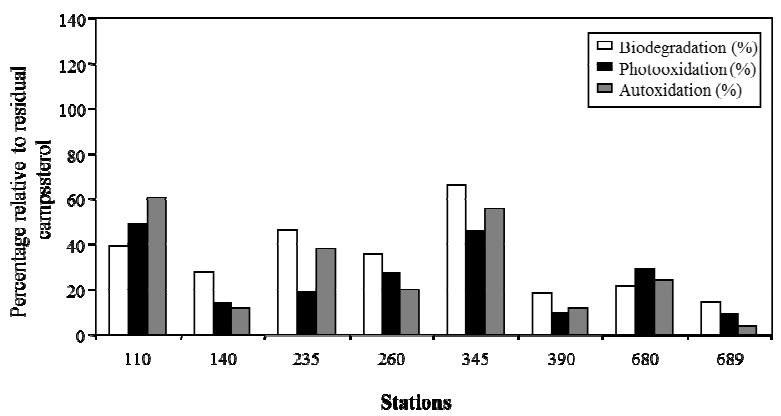

Fig. 4. Estimates of relative biodegradation, autoxidation and photooxidation (as percentages relative to the residual parent compound) of brassicasterol (A), sitosterol (B) and campesterol (C) for the different sediments investigated.

cells of Emiliania huxleyi by solar light. It was previously shown that the photodegradation of cis-vaccenic acid of heterotrophic bacteria was more than two orders of magnitude faster in the presence of phytoplanktonic cells (Rontani et al., 2003). Indeed, phytodetritus constitute hydrophobic microenvironments where the lifetime and potential diffusive distance of singlet oxygen may be long enough to allow its transfer to attached heterotrophic bacteria. Damages resulting from the presence of high amounts of singlet oxygen in heterotrophic bacteria may thus be more important than in senescent phytoplanktonic cells due to the lack of an adapted photoprotective system in these organisms (Garcia-Pichel, 1994). Vaccenic acid also appeared to be affected by autoxidation (Fig. 5a). Reaction of singlet oxygen with unsaturated components of the outer lipopolysaccharide membrane of Gram-negative bacteria (the dominant bacteria in the ocean) leads to the formation of reactive secondary products, such as peroxyl radicals, which may in turn accentuate cell damages (Dahl et al., 1989). The predominance of autoxidation
$\mathbf{A}$
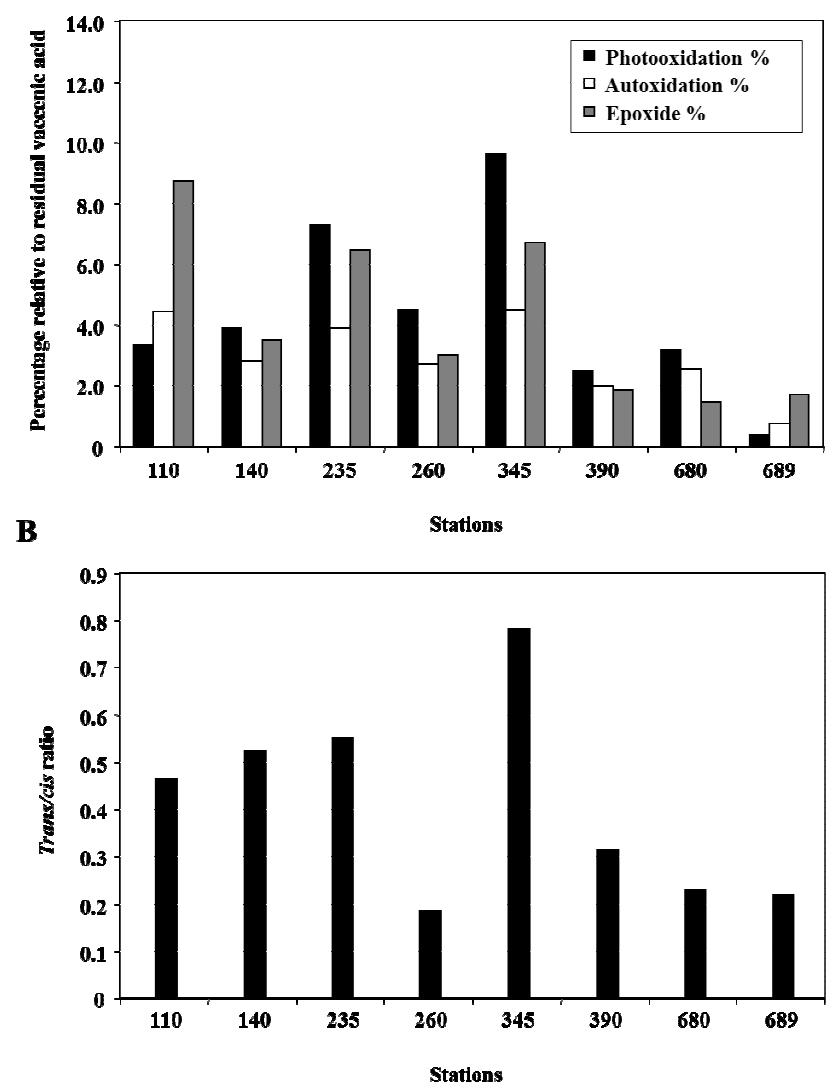

Fig. 5. Estimates of relative autoxidation, photooxidation and epoxide production (as percentages relative to the residual parent compound) (A) and trans / cis ratio measured (B) of vaccenic acid for the different sediments investigated.

relative to photooxidation observed in the case of palmitoleic acid (Fig. 7a) was attributed to a strong contribution of benthic animals (where Type II photoprocesses do not act) to this fatty acid.

We detected significant proportions of saturated hydroxyacids, methoxyhydrins, diols and chlorohydrins resulting from the degradation of 9,10-epoxyhexadecanoic, 9,10epoxyoctadecanoic and 11,12-epoxyoctadecanoic acids in the different samples investigated (Fig. 8). Epoxy acids are in fact strongly degraded during the treatment; in addition to a partial reduction with $\mathrm{NaBH}_{4}$ (Marchand and Rontani, 2001), they undergo alcoholysis and hydrolysis during alkaline hydrolysis and are converted to chlorohydrins and 9,10dihydroxyacids during acidification (Holloway and Brown Deas, 1973; Fig. 8). Epoxides may be formed by classical addition of a peroxyl radical to a double bond (Berti, 1973) and subsequent fast intramolecular homolytic substitution (Fossey et al., 1995). However, this reaction becomes competitive (relative to allylic hydrogen atom abstraction) only in the case of conjugated, terminal, or trisubstituted 
Table 2. Fatty acid content $\left(\mu \mathrm{g} \mathrm{g}^{-1}\right)$ of the sediments investigated.

\begin{tabular}{|c|c|c|c|c|c|c|c|c|}
\hline Fatty acids & 110 & 140 & 235 & 260 & 345 & 390 & 680 & 689 \\
\hline $\mathrm{C}_{14: 0}$ (Myristic acid) & 46.4 & 254.3 & 65.9 & 102.0 & 72.3 & 253.9 & 259.2 & 151.9 \\
\hline $\mathrm{C}_{15: 0}$ (Pentadecanoic acid) & 18.1 & 32.1 & 28.0 & 79.1 & 24.7 & 36.4 & 38.0 & 25.2 \\
\hline $\mathrm{C}_{16: 1 \Delta 9}$ (Cis palmitoleic acid $)$ & 30.7 & 2010.7 & 70.5 & 28.3 & 63.3 & 1237.3 & 1220.8 & 796.5 \\
\hline $\mathrm{C}_{16: 1 \Delta 9}$ (Trans palmitoleic acid) & 3.0 & 48.3 & 4.2 & 0.2 & 3.2 & 22.3 & 111.1 & 4.8 \\
\hline $\mathrm{C}_{16: 0}$ (Palmitic acid) & 171.7 & 613.0 & 321.4 & 982.8 & 309.3 & 631.9 & 713.7 & 447.5 \\
\hline $\mathrm{C}_{18: 1 \Delta 9 \text { cis }}$ (Oleic acid) & 45.0 & 230.3 & 135.9 & 338.2 & 153.7 & 208.0 & 157.5 & 133.6 \\
\hline ans (Elaidic acid) & 22.4 & 70.9 & 28.3 & 10.1 & 67.2 & 32.7 & 27.9 & 13.3 \\
\hline $\mathrm{C}_{18: 1 \Delta 11 \text { cis }}($ Cis vaccenic acid $)$ & 87.2 & 231.4 & 68.8 & 12.2 & 107.8 & 269.4 & 213.1 & 278.1 \\
\hline $\mathrm{C}_{18: 1 \Delta 11 \text { trans (Trans vaccenic acid) }}$ & 40.4 & 120.8 & 37.8 & 2.3 & 84.1 & 84.1 & 48.4 & 60.6 \\
\hline $\mathrm{C}_{18: 0}$ (Stearic acid) & 50.1 & 149.7 & 82.7 & 310.4 & 107.4 & 103.0 & 80.6 & 65.7 \\
\hline
\end{tabular}

A

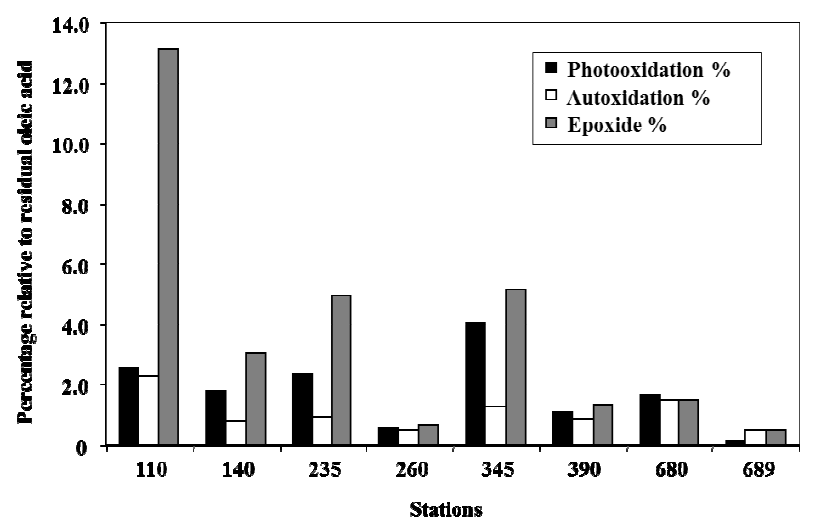

B

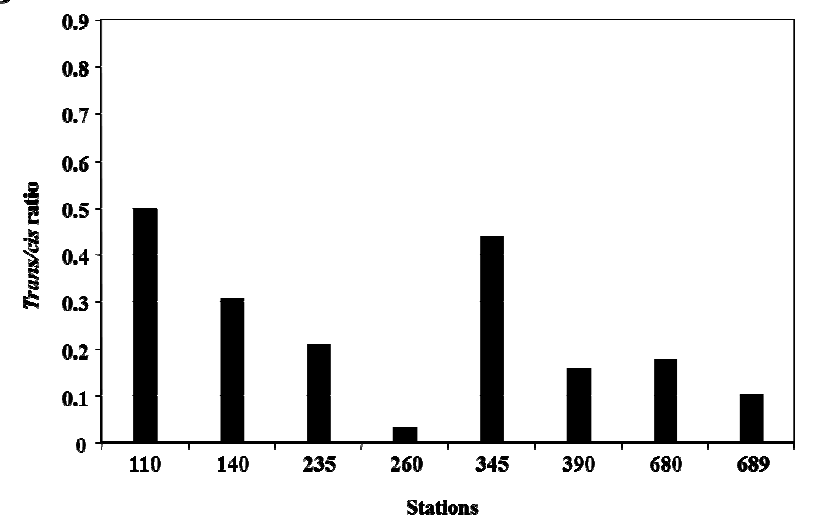

Fig. 6. Estimates of relative autoxidation, photooxidation and epoxide production (as percentages relative to the residual parent compound) (A) and trans / cis ratio measured (B) of oleic acid for the different sediments investigated.

double bonds (Schaich, 2005). In the case of monounsaturated fatty acids, such a formation is thus very unlikely. Epoxidation of the double bonds of fatty acids may be also induced by cytochrome P-450-dependent monooxygenases (Ruettinger and Fulco, 1981); however, these enzymes also catalyse monohydroxylation at the $\omega-1, \omega-2$ and $\omega-3$ posi-

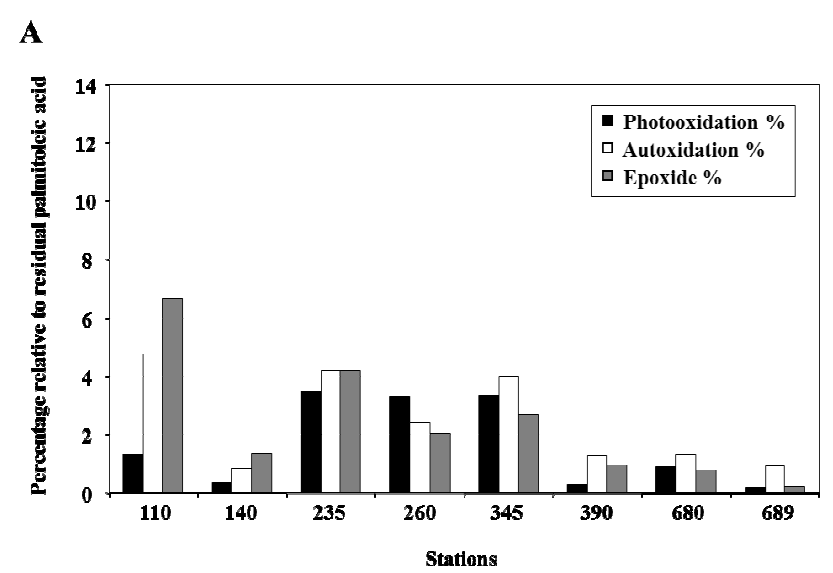

B

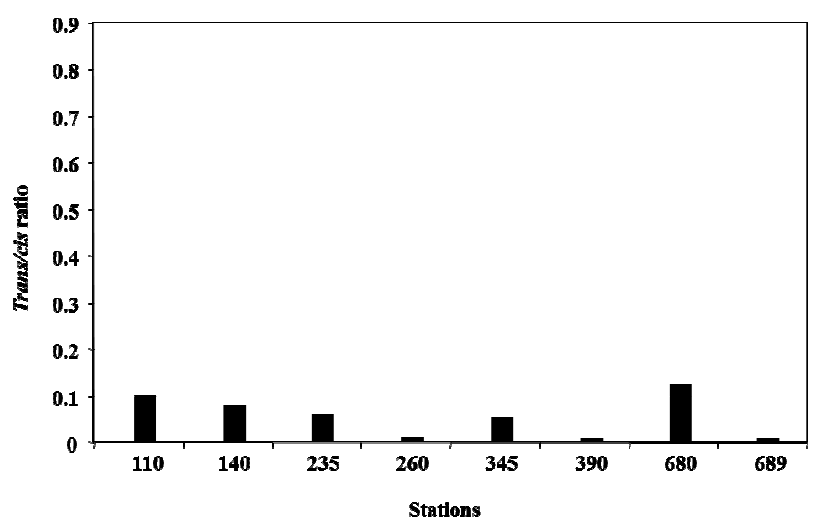

Fig. 7. Estimates of relative autoxidation, photooxidation and epoxide production (as percentages relative to the residual parent compound) (A) and trans / cis ratio measured (B) of palmitoleic acid for the different sediments investigated.

tions and we failed to detect the thus formed hydroxyacids in lipid extracts. Finally, we attributed the formation of the epoxy acids detected to the involvement of peroxygenases (hydroperoxide-dependent oxygenases) during abiotic degradation of higher plant debris, algae or bacteria. Such enzymes catalysed epoxidation of unsaturated fatty acids in the 


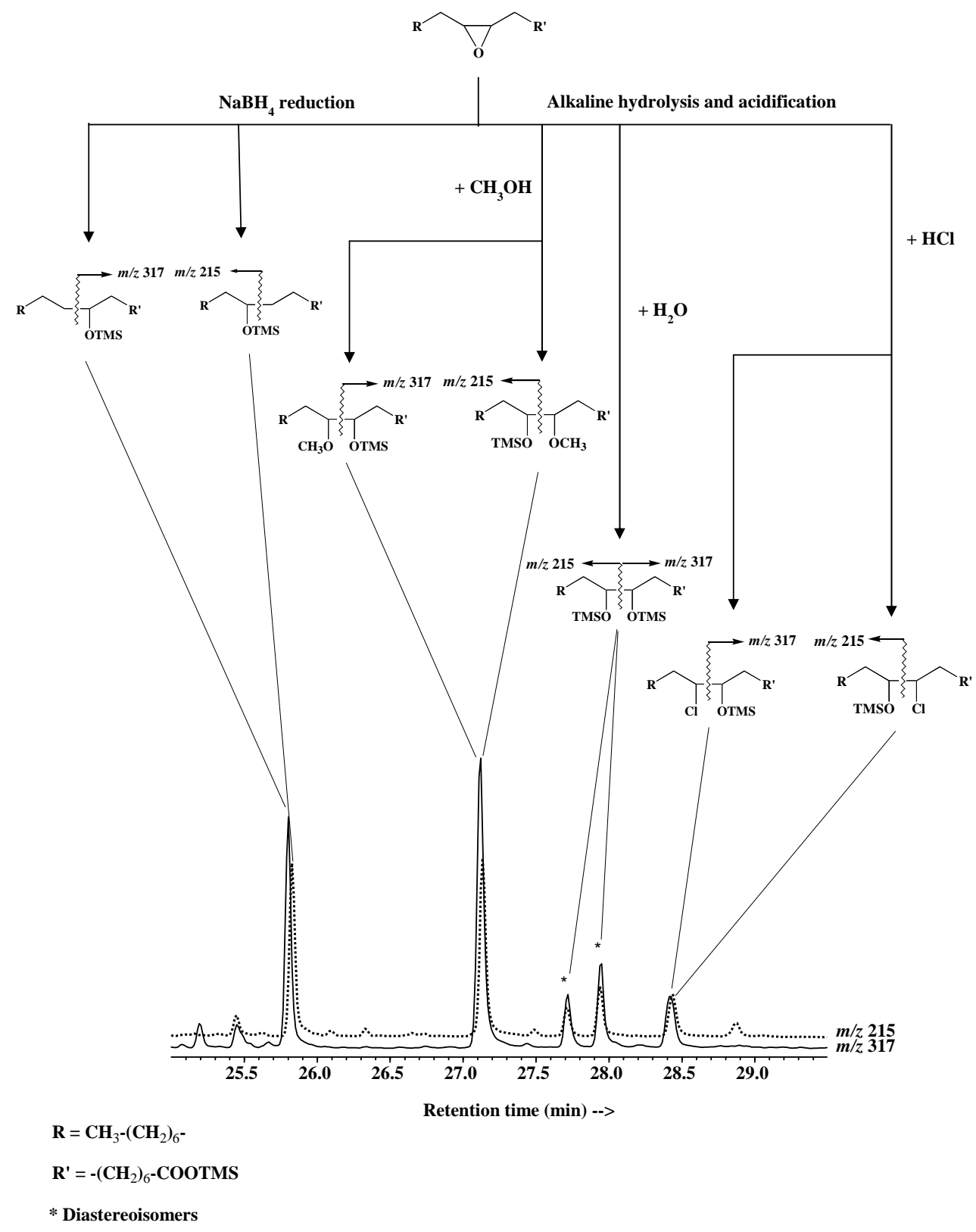

Fig. 8. Compounds resulting from the degradation of 9,10-epoxyoctadecanoic acid during the treatment.

presence of alkylhydroperoxides as co-substrates (Fig. 9) and play a protective role against the deleterious effects of fatty acid hydroperoxides in vivo (Blée and Schuber, 1990). This hypothesis is well supported by the relative good correlation observed between the proportions of epoxy acids and these of fatty acid oxidation products (quantified after $\mathrm{NaBH}_{4}$ reduction of the corresponding hydroperoxides) $\left(r^{2}=0.825\right.$, 0.702 and 0.631 with p-value $=0.002,0.009$ and 0.018 for vaccenic, oleic and palmitoleic acids, respectively; Figs. 5a, $6 a$ and $7 a)$.

While the trans / cis ratio of monounsaturated fatty acids is usually 0.05 or less in healthy non stressed bacterial popula- tions (Navarrete et al., 2000), unusually high proportions of monounsaturated fatty acids with a trans double bond could be detected in the sediments analysed. The position of the double bond of these compounds was unambiguously determined after $\mathrm{OsO}_{4}$ oxidation and GC-EIMS analyses of the silylated foregoing diastereoisomeric diols (Fig. 10). According to the fatty acid considered, well distinct trans / cis ratios could be observed (Figs. 5b, 6b and 7b). Cis-trans isomerisation of the double bond of monounsaturated fatty acids may be attributed to (i) photosensitized isomerization processes induced by UVR (Christodoulou et al., 2010) generally involving ketonic triplet energy sensitizers (Testa, 1964; 


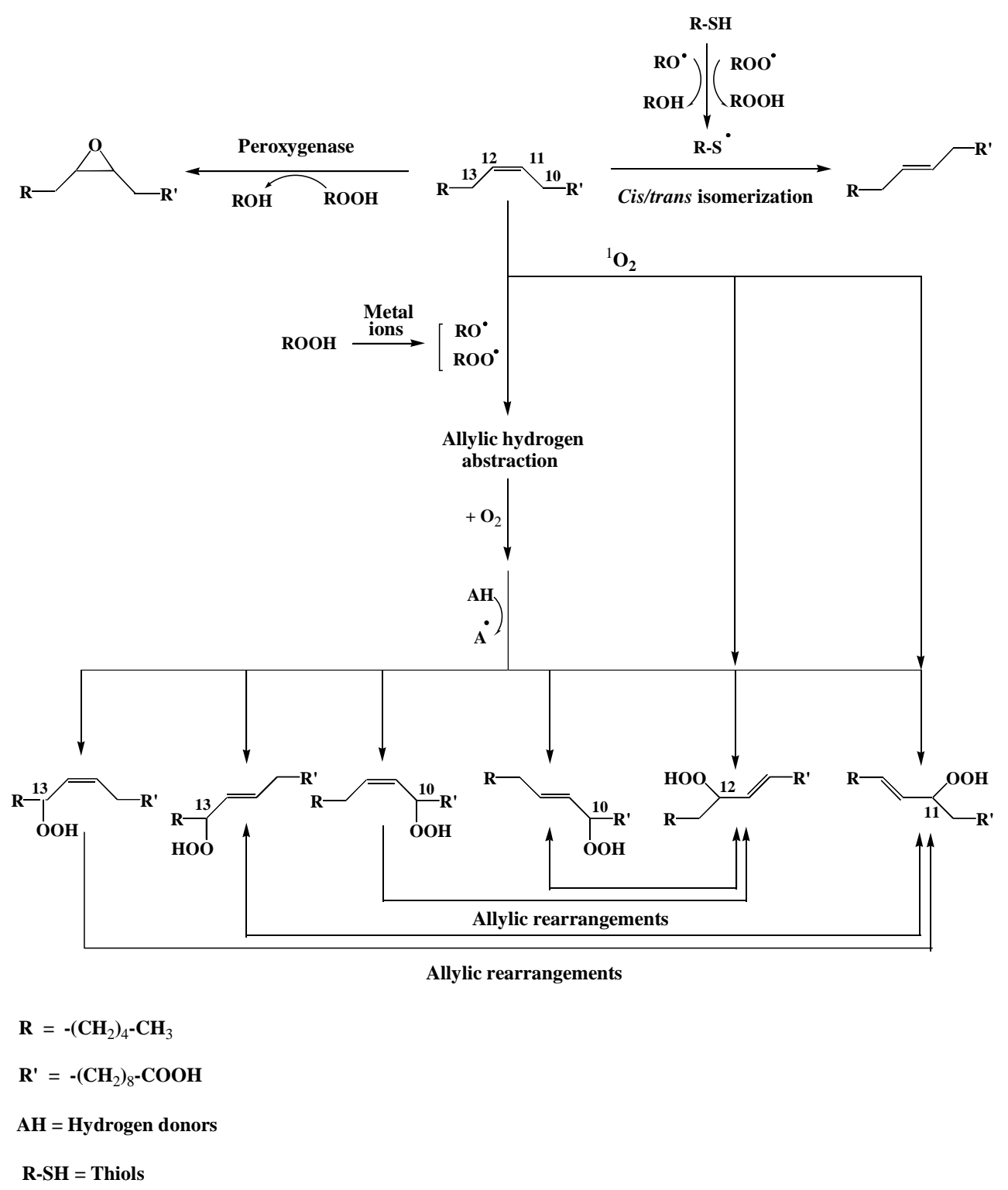

Fig. 9. Proposed mechanisms for biotic and abiotic degradation of vaccenic acid in the Beaufort Shelf.

Horspool and Armesto, 1992), (ii) cis-trans isomerase activity enabling Gram-negative bacteria belonging to the genera Pseudomonas and Vibrio to adapt to several forms of environmental stress (Heipieper et al., 2003), or (iii) the formation of thiyl radicals (catalyzing double bond isomerisation, Ferreri et al., 2004) during the antioxidant reactions of biologically relevant thiols (e.g. glutathione) (Chatgilialoglu et al., 2002) or after methanethiol homolytic cleavage or thiolate oxidation.

During previous irradiation of non-axenic cells of the haptophyte E. huxleyi by solar light, it was observed that UVRinduced photosensitized cis-trans isomerisation processes acted not only on monounsaturated fatty acids but also on their oxidation products (Christodoulou et al., 2010). In the studied sediments, the lack of 9-cis and 10-cis hydroxyacids (arising from oleic acid oxidation) and 11-cis and 12-cis hydroxyacids (arising from cis-vaccenic acid oxidation) previously proposed as potential tracers of the effects of UVR insitu (Christodoulou et al., 2010) suggests that cis-trans isomerisation of monounsaturated fatty acids observed in sediments from the Beaufort Shelf does not result from the involvement of UVR-induced photosensitized processes in the water column.

Enzymatic cis-trans isomerisation of unsaturated fatty acids constitutes an important adaptive reaction of Pseudomonas and Vibrio species to toxic organic compounds or other environmental stress factors (Heipieper et al., 1992, 2003 , 2007). Such an adaptive mechanism appears to be 
A

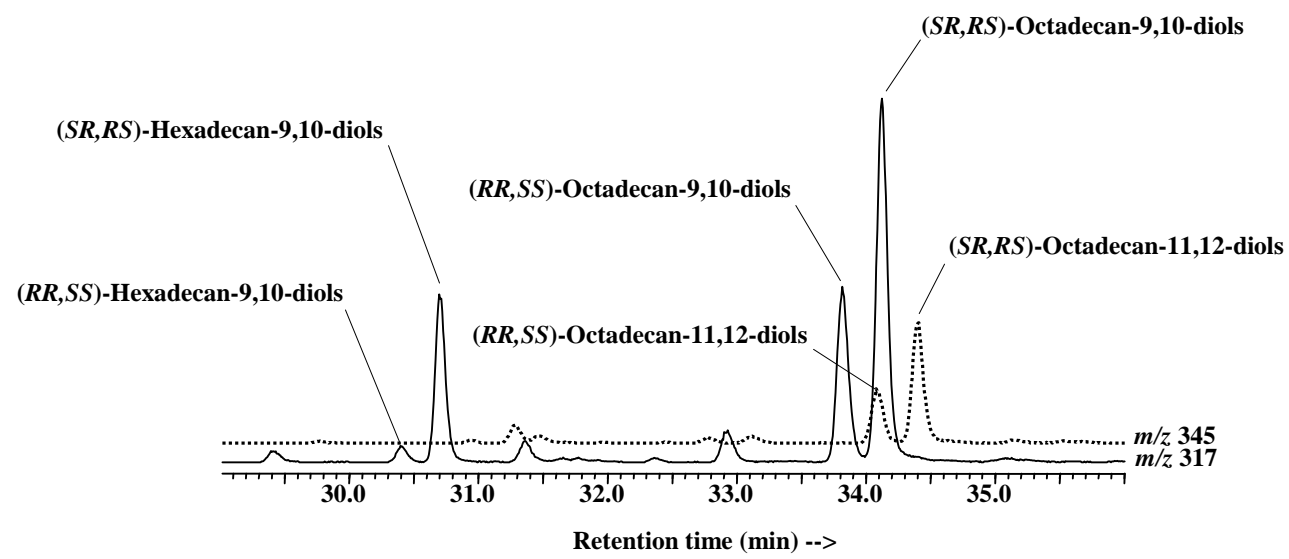

B

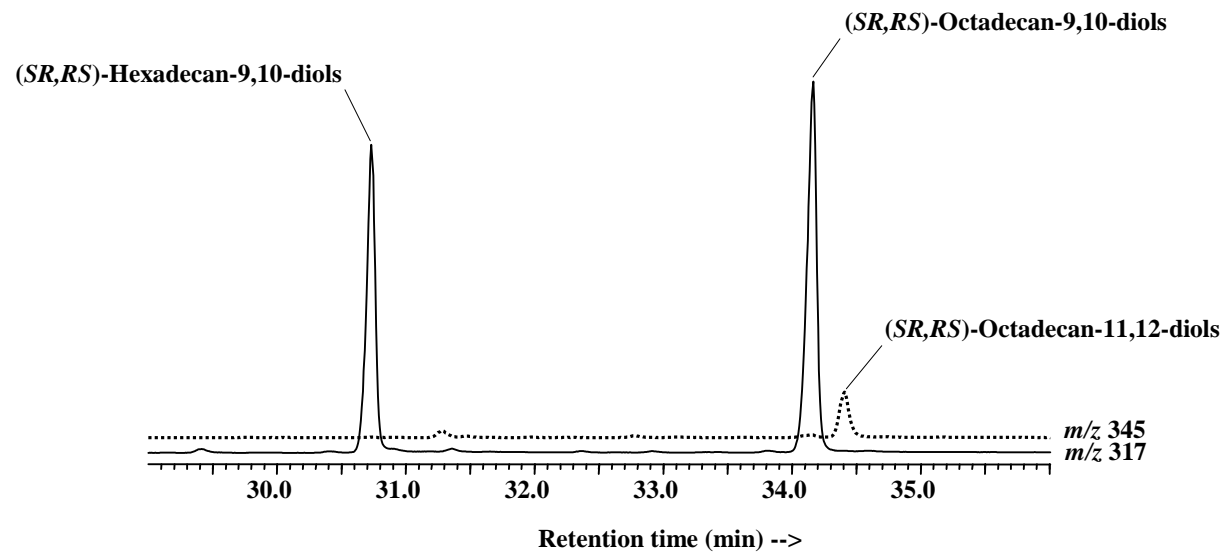

Fig. 10. Partial $\mathrm{m} / \mathrm{z} 317$ and 345 ion chromatograms showing the distribution of silylated $\mathrm{OsO}_{4}$ derivatives of cis and trans monounsaturated fatty acids in surface sediments $(0-1 \mathrm{~cm})$ collected at the stations 110 (A) and 260 (B).

an alternative way to regulate membrane fluidity when the growth is inhibited (Heipieper et al., 2003). Based on the good correlation observed between the hydrophobicity of organic compounds, growth inhibition and the trans/cis ratio of unsaturated fatty acids, this enzymatic isomerisation process was proposed as a marker for stress in contaminated environments (Guckert et al., 1986; Frostegard et al., 1993; White et al., 1996). Values of the trans / cis ratio higher than 0.1 in environmental samples are generally considered as indicative of environmental stress conditions at the site (Guckert et al., 1986; Navarrete et al., 2000). The very high trans / cis ratio observed in the sediments analysed (values ranging from 0.03 to 0.50 for oleic acid and from 0.18 to 0.78 for vaccenic acid; Figs. 5b and 6b) could thus be attributed to an adaptive reaction of sedimentary bacteria to the presence of high amounts of photochemically and autoxidatively- produced hydroperoxides in sinking particles (Rontani et al., $2012 b$ ) reaching these sediments. However, it was previously demonstrated that this enzymatic isomerisation process has a highest specificity for $\mathrm{C}_{16}$ unsaturated fatty acids as substrates (Heipieper et al., 1992) and the trans/cis ratio observed in the samples for palmitoleic acid (values ranging from 0.004 to 0.1 ; Fig. $7 b$ ) are considerably lower than in the case of oleic and vaccenic acids (Figs. 5b and 6b). In addition, it was recently shown that the cis-trans isomerisation is only an urgent response mechanism in these bacteria that is later substituted by other adaptive mechanisms (Fischer et al., 2010). Therefore, the trans/cis ratio is not a good indicator of long-term oxidative stress as it is present in the investigated sediments. It seems thus very unlikely that the formation of trans monounsaturated fatty acids in sediments 
from the Beaufort Shelf results from an enzymatic cis-trans isomerisation activity.

Functionalised aliphatic thiols (glutathione, methioninecontaining proteins) are present in living organisms in considerable amounts (Ferreri et al., 2005). These compounds, which are very good hydrogen donors towards radicals, such as alkoxyl or alkylperoxyl radicals, are extraordinarily efficient antioxidants protecting the cells against consequences of damage induced by free radicals (Wlodek, 2002) (Eqs. 1$3)$.

$$
\begin{aligned}
& \mathrm{R}-\mathrm{S}-\mathrm{H}+\mathrm{R}-\mathrm{O}^{\bullet} \rightarrow \mathrm{R}-\mathrm{S}^{\bullet}+\mathrm{R}-\mathrm{O}-\mathrm{H} \\
& \mathrm{R}-\mathrm{S}-\mathrm{H}+\mathrm{R}-\mathrm{O}-\mathrm{O}^{\bullet} \rightarrow \mathrm{R}^{\bullet} \mathrm{S}^{\bullet}+\mathrm{R}-\mathrm{O}-\mathrm{O}-\mathrm{H}
\end{aligned}
$$

$2 \mathrm{R}-\mathrm{S}-\mathrm{H}+\mathrm{R}-\mathrm{O}-\mathrm{O}-\mathrm{H} \rightarrow 2 \mathrm{R}-\mathrm{S}^{\bullet}+\mathrm{R}-\mathrm{O}-\mathrm{H}+\mathrm{H}_{2} \mathrm{O}$

However, this role as repairing agents is counterbalanced by the formation of thiyl radical species, which can damage other biomolecules (Ferreri et al., 2005; Rontani et al., 2006). Indeed, thiyl radicals are efficient catalysts for cis-trans isomerisation of lipids in biological membranes and this process cannot be ignored when considering radical damage to biological components. In sediments, the formation of thiyl radicals can also result from the homolytic cleavage of methanethiol produced by bacteria. Several mechanisms for the bacterial production of methanethiol in the environment have been identified. It can be formed by (i) microbial degradation of S-containing amino acids such as methionine (Eq. 4; Ferchichi et al., 1986; Kiene and Visscher, 1987), (ii) methylation of sulfide (Eq. 5; Lomans et al., 2002) and (iii) degradation of $\beta$-dimethylsulfoniopropionate (DMSP) (Eqs. 6 and 7), a tertiary sulfonium compound produced in high concentration by certain species of algae (Keller et al., 1989; Yoch, 2002) and halophytes (Ishida, 1996) for regulation of their internal osmotic environment.

$$
\begin{aligned}
& \mathrm{CH}_{3}-\mathrm{S}-\mathrm{CH}_{2}-\mathrm{CH}_{2}-\mathrm{CH}\left(\mathrm{NH}_{2}\right)-\mathrm{COOH} \\
& \rightarrow \mathrm{CH}_{3} \mathrm{SH}+\mathrm{CH}_{3}-\mathrm{CH}_{2}-\mathrm{CO}-\mathrm{COOH}+\mathrm{NH}_{3}
\end{aligned}
$$

$(\mathrm{S}, \mathrm{S})$-adenosylmethionine $+\mathrm{SH}^{-}$

$\rightarrow(\mathrm{S})$-adenosylhomocysteine $+\mathrm{CH}_{3} \mathrm{SH}$

$$
\begin{aligned}
& \left(\mathrm{CH}_{3}\right)_{2}-\mathrm{S}^{+}-\mathrm{CH}_{2}-\mathrm{CH}_{2}-\mathrm{COO}^{-} \rightarrow \mathrm{CH}_{3}-\mathrm{S}_{-}-\mathrm{CH}_{2}-\mathrm{CH}_{2}-\mathrm{COO}^{-} \\
& \rightarrow \mathrm{CH}_{3} \mathrm{SH}+\mathrm{CH}_{2}=\mathrm{CH}-\mathrm{COO}^{-}
\end{aligned}
$$

$$
\begin{aligned}
& \left(\mathrm{CH}_{3}\right)_{2}-\mathrm{S}^{+}-\mathrm{CH}_{2}-\mathrm{CH}_{2}-\mathrm{COO}^{-} \\
& \rightarrow \mathrm{CH}_{2}=\mathrm{CH}-\mathrm{COO}^{-}+\mathrm{CH}_{3}-\mathrm{S}-\mathrm{CH}_{3} \rightarrow \mathrm{CH}_{3} \mathrm{SH}
\end{aligned}
$$

Thiyl radicals can also be produced by oxidation of thiolate ions (produced during sulfate reduction) by transition metals, e.g. $\mathrm{Fe}^{+3}$ (Eq. 8; Wlodek, 2002).

$$
\mathrm{HS}^{-}+\mathrm{Fe}^{+3} \rightarrow \mathrm{HS}^{\bullet}+\mathrm{Fe}^{+2}
$$

The fact that thiyl radicals act as a catalyst for cis-trans isomerisation is important, because even a small concentration of these radical species is able to propagate the reaction, leading to an efficient formation of trans isomers (Ferreri et al., 2007). Because the trans-configuration is energetically preferred by about $0.6-1 \mathrm{kcal} \mathrm{mol}^{-1}$, a mixture dominated by trans olefin (about $80 \%$ ) may be theoretically obtained (Ferreri et al., 2005). Due to the presence of significant amounts of intact hydroperoxides in sinking particles reaching these sediments (Rontani et al., 2012b), an induction of cis-trans isomerisation by thiyl radicals resulting from the reaction of thiols with hydroperoxides (Fig. 9) seems thus very likely. This hypothesis is well supported by the relative good correlation observed between the trans/cis ratio and the proportions of vaccenic and oleic acid oxidation products (quantified after $\mathrm{NaBH}_{4}$-reduction of the corresponding hydroperoxides) $\left(r^{2}=0.692\right.$ and 0.812 with p-value $=0.011$ and 0.002, respectively; Figs. 5 and 6). These processes appeared to act very intensively in bacteria and to a lesser extent in phytodetritus and higher plant debris.

It may be noted that the trans configuration of double bonds is 7 to 10 times less sensitive against singlet oxygenmediated oxidation than the classical cis configuration (Hurst et al., 1985). Consequently, if cis-trans isomerisation processes took place in sinking particles, which are generally considered as the main contributors to the sedimentary record (Wakeham and Lee, 1989), selective Type II photooxidation of cis and trans monounsaturated fatty acids in euphotic layer could be an additional explanation of the unusually high trans/cis ratio observed in sediments. Recent analyses of particles collected by traps in this zone allowed us to show that the formation of trans monounsaturated fatty acids does not act in sinking particles (Rontani et al., 2012b) and thus to exclude such a possibility.

While algal OM appeared to be weakly degraded in all the sediments investigated (Fig. 4a), a strong spatial variability of the autoxidative degradation state of terrestrial OM was observed (Fig. 4b and c). This variability could be related to the position of the stations relative to the Mackenzie mouth. Indeed, a strong autoxidation of terrestrial OM in SPM was previously observed in the mixing zone of the Mackenzie (Rontani et al., 2012a). The extent of autoxidation appeared to be well correlated with salinity, suggesting that these free radical oxidation processes are enhanced by contact with seawater. Consequently, the stations more distant from the Mackenzie, where the residence time of terrestrial OM in seawater is expected to have been longest, should exhibit the highest autoxidation states. The results obtained well support this assumption. Indeed, the highest autoxidation states were observed at the stations 110, 235 and 345 (Fig. 4b and c), which are very distant from the Mackenzie, while the station 689 close to the mouth (Fig. 1) exhibited the weakest degradation state (Fig. $4 \mathrm{~b}$ and c). It is interesting to note that Link et al. (2012), which used chlorophylla/phaeopigment ratio as a proxy of the quality or "freshness" 
of the organic matter supply, also observed the highest degradation states at the stations 110, 235 and 345 .

The biogeochemical fluxes measured at the same stations by Link et al. (2012) showed the highest oxygen demands for the inner shelf sediments (stations 689, 680, 390, and 260). These oxygen demands, which were associated with high production rates of metabolites (e.g. $\mathrm{NO}_{2}^{-}, \mathrm{PO}_{4}^{3-}, \mathrm{NH}_{4}^{+}$), are indicative of an intense biodegradation activity in these sediments. These results are in good agreement with the weak degradation state and the cis/trans ratio of vaccenic acid measured at these stations (Fig. 5) attesting to the presence of non-stressed bacteria in a good healthy state and thus very active.

\section{Conclusions}

Lipids and their degradation products were quantified in eight samples of surface sediments collected in the Beaufort Sea. Brassicasterol (mainly arising from phytoplankton) appeared to be very weakly affected by biotic and abiotic degradation processes in these sediments. These results do not support the generally expected quick recycling of material derived from primary production in the water column and/or at the sediment interface of this zone (Magen et al., 2010). In contrast, autoxidation, photooxidation and biodegradation processes acted intensively on sitosterol and campesterol (mainly arising from terrestrial higher plants), while these compounds appeared to be only photodegraded in particulate matter delivered by the Mackenzie River (Rontani et al., 2012a). The old concept expecting that the pre-degradation of terrestrial $\mathrm{OM}$ on land and in the rivers should result in a good preservation of this material in the marine environment seems thus to be erroneous.

In the Arctic, global warming may induce changes in vegetation from tundra toward leaf-bearing plants (Goñi et al., 2005), thus enhancing the delivery of modern vascular plant organic carbon to rivers. To estimate the consequences of climate change in this strategic zone, a good knowledge of the processes controlling degradation and burial of terrestrial $\mathrm{OM}$ is essential. The results obtained here confirm that vascular plant POM delivered by the Mackenzie River to the Beaufort Sea is strongly affected by biotic and abiotic degradation processes.

We used oxidation products of vaccenic acid, which is a typical biomarker for Gram-negative bacteria (Sicre et al., 1988; Keweloh and Heipieper, 1996), to estimate the extent of abiotic sedimentary bacteria degradation. In contrast, oxidation products of the non-specific oleic and palmitoleic acids could only be used to assess abiotic degradation of bulk OM of sediments. Surprisingly, photo- and autoxidation processes appeared to act more intensively in bacteria than in other organisms. We suggest that singlet oxygen is efficiently transferred from phytodetritus, where it is produced by photolytic excitation of chlorophyll, to the heterotrophic bacteria (and their lipids) that are associated with the detritus. This transfer has been observed previously in vitro (Rontani et al., 2003; Christodoulou et al., 2010). The highest efficiency of oxidative damages in bacteria should result from the lack of an adapted antioxidant system in these microorganisms (Garcia-Pichel, 1994).

In parallel to the intensive abiotic degradation of monounsaturated fatty acids observed, significant amounts of epoxy acids could be detected. The formation of these compounds was attributed to the involvement of peroxygenases (hydroperoxide-dependent oxygenases) during abiotic degradation of higher plant debris, algae or bacteria contained in sediments. Such enzymes play a protective role against the deleterious effects of fatty acid hydroperoxides in vivo.

Unusually high proportions of monounsaturated fatty acids with a trans double bond could be also detected in these sediments. Vaccenic, oleic and palmitoleic acids exhibited well distinct trans / cis ratios, the highest values (ranging from 0.18 to 0.78 ) being observed in the case of vaccenic acid. Due to the strong oxidative stress observed in the sediments investigated, induction of cis-trans isomerisation was attributed to the presence of thiyl radicals resulting from the reaction of thiols with hydroperoxides. These processes appeared to act very intensively in bacteria and to a lesser extent in phytodetritus and higher plant debris.

Acknowledgements. Financial support from the Centre National de la Recherche Scientifique (CNRS) and the Universite d'AixMarseille is gratefully acknowledged. This study was conducted as part of the Malina Scientific Program funded by ANR (Agence nationale de la recherche), INSU-CNRS (Institut national des sciences de l'univers - Centre national de la recherche scientifique), CNES (Centre national d'études spatiales) and ESA (European Space Agency). We would like to thank M. Babin, chief scientist of the cruise and coordinator of the MALINA program. Funding was also provided by the Canadian Healthy Oceans Network (CHONe) and ArcticNet and partially by the Fonds québécois de la recherche sur la nature et les technologies (FQRNT), and Québec-Océan, for H. Link and by the Canada Research Chair program for G. Chaillou. This work was carried out in the framework of the transverse axis DEBAT (DEgradation Biotique et Abiotique de la maTière organique en milieu marin: processus et interactions) of the MIO. We are grateful to M. B. Yunker and an anonymous referee for their useful and constructive comments.

Edited by: M. Babin

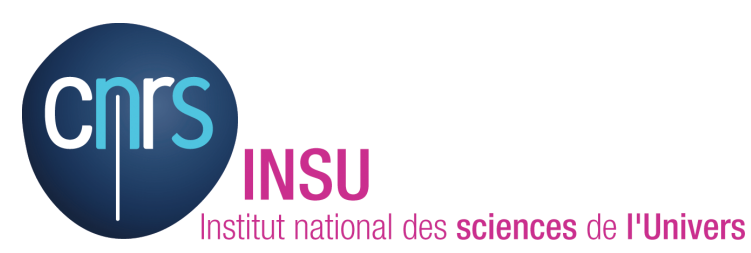

The publication of this article is financed by CNRS-INSU. 


\section{References}

Alkhatib, M., Schubert, C. J., del Giorgio, P. A., Gelinas, Y., and Lehmann, M. F.: Organic matter reactivity indicators in sediments of the St. Lawrence Estuary, Estuar. Coast. Shelf. Sci., 102-103, 36-47, 2012.

Babin, M., Bélanger, S., Devred, E., Doxaran, D., Forest, A., Gratton, Y., Lansard, B., Marec, C., Matsuoka, A., Prieur, L., Raimbault, P., and Tremblay, J.-E.: How do changes in ice cover, permafrost and UV radiation impact on biodiversity and biogeochemical fluxes in the Arctic Ocean? The Malina project and field expedition, Biogeosciences Discuss., in preparation, 2012.

Belicka, L. L., Macdonald, R. W., Yunker, M. B., and Harvey, H. R.: The role of depositional regime on carbon transport and preservation in Arctic Ocean sediments, Mar. Chem., 86, 65-88, 2004.

Berner, R. A.: Burial of organic carbon and pyrite sulphur in the modern ocean: its geochemical and environmental significance, Am. J. Sci., 282, 451-473, 1982.

Berti, G.: Stereochemical aspects of the synthesis of 1,2-epoxides, in: Topics in Stereochemistry, edited by: Allinger, N. L. and Eliel, E. L., Interscience Publishers, New York, 95-234, 1973.

Bianchi, T. S.: The role of terrestrially derived organic carbon in the coastal ocean: A changing paradigm and the priming effect, $\mathrm{P}$. Natl. Acad. Sci., 108, 19473-19481, 2011.

Blasco, S., Shearer, J., and Myers, R.: Seabed scouring by sea-ice: Scouring process and impact rates, Canadian Beaufort Shelf, in: Proceedings of Ice Scour and Arctic Marine Pipelines Workshop, 13th International Symposium on Okhotsk Sea and Sea Ice, 1998.

Blée, E. and Schuber, F.: Efficient epoxidation of unsaturated fatty acids by a hydroperoxide-dependent oxygenase, J. Biol. Chem., 265, 12887-12894, 1990.

Bortolomeazzi, R., De Zan, M., Pizzale, L., and Conte, L. S.: Mass spectrometry characterization of the $5 \alpha-, 7 \alpha$, and $7 \beta$-hydroxy derivatives of $\beta$-sitosterol, campesterol, stigmasterol and brassicasterol, J. Agric. Food Chem., 47, 3069-3074, 1999.

Bourgeois, S., Pruski, A. M., Sun, M.-Y., Buscail, R., Lantoine, F., Kerhervé, P., Vétion, G., Rivière, B., and Charles, F.: Distribution and lability of land-derived organic matter in the surface sediments of the Rhône prodelta and the adjacent shelf (Mediterranean Sea, France): a multi proxy study, Biogeosciences, 8, 3107-3125, doi:10.5194/bg-8-3107-2011, 2011.

Bringué, M. and Rochon, A.: Late Holocene paleoceanography and climate variability over the Mackenzie Slope (Beaufort Sea, Canadian Arctic), Mar. Geol., 291-294, 83-96, 2012.

Brunskill, G. J.: Environmental features of the Mackenzie system, in: The ecology of river systems, edited by: Davis, B. R. and Walker, W. F., Dordrecht, The Netherlands, Dr. W. Junk Publications, 435-471, 1986.

Canuel, E. A. and Martens, C. S.: Reactivity of recently deposited organic matter: Degradation of lipid compounds near the sediment-water interface, Geochim. Cosmochim. Ac., 60, 17931806, 1996.

Chatgilialoglu, C., Altieri, A., and Fischer, H.: The kinetics of thiyl radical-induced reactions of monounsaturated fatty acid esters, J. Am. Chem. Soc., 124, 12816-12823, 2002.

Christodoulou, S., Marty, J.-C., Miquel, J.-C., Volkman, J. K., and Rontani, J.-F.: Use of lipids and their degradation products as biomarkers for carbon cycling in the northwestern Mediterranean Sea, Mar. Chem., 113, 25-40, 2009.
Christodoulou, S., Joux, F., Marty, J.-C., Sempéré, R., and Rontani, J.-F.: Comparative study of UV and visible light induced degradation of lipids in non-axenic senescent cells of Emiliania huxleyi, Mar. Chem., 119, 139-152, 2010.

Conlan, K., Aitken, A., Hendrycks, E., McClelland, C., and Melling, H.: Distribution patterns of Canadian Beaufort Shelf macrobenthos, J. Mar. Syst., 74, 864-886, 2008.

Dahl, T. A., Midden, W. R., and Hartman, P. E.: Comparison of killing of Gram-negative and Gram-positive bacteria by pure singlet oxygen, J. Bacteriol., 171, 2188-2194, 1989.

De Leeuw, J. W. and Baas, M.: Early stage diagenesis of steroids, in: Biological Markers in the Sedimentary Record, edited by: Johns, R. B., Elsevier, 101-123, 1986.

De Leeuw, J. W. and Largeau, C.: A review of macromolecular organic compounds that comprise living organisms and their role in kerogen, coal, and petroleum formation, in: Organic Geochemistry Principles and Applications, edited by: Engel, M. H. and Macko, S. A., Plenum Publishing, New York, 23-72, 1993.

Fahl, K., Stein, R., Gaye-Haake, B., Gebhardt, C., Kodina, L. A., Unger, D., and Ittekkot, V.: Biomarkers in surface sediments from the $\mathrm{Ob}$ and Yenisei estuaries and the southern Kara Sea: evidence for particulate organic carbon sources, pathways, and degradation, in: Proceedings in Marine Science 6: Siberian River Run-off in the Kara Sea, edited by: Stein, R., Fahl, K., Fütterer, D. K., Galimov, E. M., and Stepanets, O. V., Elsevier Science, 329-348, 2003.

Ferchichi, M., Hemme, D., and Nardi, M.: Induction of methanethiol production by Brevibacterium linens CNRZ 918, J. Gen. Microbiol., 132, 3075-3082, 1986.

Ferreri, C., Samadi, A., Sassatelli, F., Landi, L., and Chatgilialoglu, C.: regioselective cis-trans isomerization of arachidonic double bonds by thiyl radicals: the influence of phospholipids supramolecular organization, J. Am. Chem. Soc., 126, 1063 $1072,2004$.

Ferreri, C., Kratzsch, S., Landi, L., and Brede, O.: Thiyl radicals in biosystems: effects on lipid structures and metabolisms, Cell. Mol. Life Sci., 62, 834-847, 2005.

Ferreri, C., Panagiotaki, M., and Chatgilialoglu, C.: Trans fatty acids in membranes: the free radical path, Mol. Biotechnol., 37, 19-25, 2007.

Fischer J., Schauer F., and Heipieper H. J.: The trans/cis ratio of unsaturated fatty acids is not applicable as biomarker for environmental stress in case of long-term contaminated habitats, Appl. Microbiol. Biotechnol., 87, 365-371, 2010.

Fossey, J., Lefort, D., and Sorba, J.: Free radicals in organic chemistry, Masson, Paris, 1-307, 1995.

Frankel, E. N.: Lipid Oxidation, the Oily Press, Dundee, 1-303, 1998.

Frimer, A. A.: The reaction of singlet oxygen with olefins: the question of mechanism, Chem. Rev., 79, 359-387, 1979.

Frostegard, A., Baath, E., and Tunlid, A.: Shifts in the structure of soil microbial communities in limed forests as revealed by phospholipids fatty acid analysis, Soil. Biol. Biochem., 25, 723-730, 1993.

Gagosian, R. B., Peltzer, E. T., and Merrill, J. T.: Long-range transport of terrestrially derived lipids in aerosols from the south $\mathrm{Pa}$ cific, Nature, 325, 800-803, 1987.

Garcia-Pichel, F.: A model for internal self-shading in planktonic organisms and its implications for the usefulness of ultraviolet 
sunscreens, Limnol. Oceanogr., 39, 1704-1717, 1994.

Goñi, M. A., Yunker, M. B., Macdonald, R. W., and Eglinton, T. I.: Distribution and sources of organic biomarkers in arctic sediments from the Mackenzie River and Beaufort Shelf, Mar. Chem., 71, 23-51, 2000.

Goñi, M. A., Yunker, M. B., Macdonald, R. W., and Eglinton, T. I.: The supply and preservation of ancient and modern components of organic carbon in the Canadian Beaufort Shelf of the Arctic Ocean, Mar. Chem., 93, 53-73, 2005.

Griffith, D. R., McNichol, A. P., Xu, L., McLaughlin, F. A., Macdonald, R. W., Brown, K. A., and Eglinton, T. I.: Carbon dynamics in the western Arctic Ocean: insights from full-depth carbon isotope profiles of DIC, DOC, and POC, Biogeosciences, 9, 1217-1224, doi:10.5194/bg-9-1217-2012, 2012.

Guckert, J. B., Hood, M. A., and White, D. C.: Phospholipids esterlinked fatty acid profile changes during nutrient deprivation of Vibrio cholerae: increases in the trans/cis ratio and proportions of cyclopropyl fatty acids, Appl. Environ. Microbiol., 52, 794801,1986

Harwood, J. L. and Russell, N. L.: Lipids in Plants and Microbes, George Allen and Unwin, London, 1-162, 1984.

Hedges, J. I. and Keil, R. G.: Sedimentary organic matter preservation: an assessment and speculative synthesis, Mar. Chem., 49, 81-115, 1995.

Hedges, J. I., Keil, R. G., and Benner, R.: What happens to terrestrial organic matter in the ocean?, Org. Geochem., 27, 195-212, 1997.

Heipieper, H. J., Diefenbach, R., and Keweloh, H.: Conversion of cis unsaturated fatty acids to trans, a possible mechanism for the protection of phenol-degrading Pseudomonas putida $\mathrm{P} 8$ from substrate toxicity, Appl. Environ. Microbiol., 58, 1847-1852, 1992.

Heipieper, H. J., Meinhardt, F., and Segura, A.: The cis-trans isomerase of unsaturated fatty acids in Pseudomonas and Vibrio: biochemistry, molecular biology and physiological function of a unique stress adaptative mechanism, FEMS Microbial Lett., 229, $1-7,2003$.

Heipieper, H. J., Neumann, G., Cornelissen, S., and Meinhardt, F.: Solvent-tolerant bacteria for biotransformations in two-phase fermentation systems, Appl. Microbiol. Biotechnol., 74, 961-973, 2007.

Hill, P. R., Blasco, S. M., Harper, J. R., and Fissel, D. B.: Sedimentation on the Canadian Beaufort Shelf, Cont. Shelf Res., 11, $821-842,1991$.

Hill, V., Cota, G., and Stockwell, D.: Spring and summer phytoplankton communities in the Chukchi and Eastern Beaufort Seas, Deep-Sea Res., 52, 3369-3385, 2005.

Holloway, P. J. and Brown-Deas, A. H. B.: Epoxyoctadecanoic acids in plant cutins and suberins, Phytochemistry, 12, 17211735, 1973.

Holmes, R. M., McClelland, J. W., Peterson, B. J., Shiklomanov, I. A., Shiklomanov, A. I., Zhulidov, A. V., Gordeev, V. V., and Bobrovitskaya, N. N.: A circumpolar perspective on fluvial sediment flux to the Arctic Ocean, Global Biogeochem. Cy., 16, 1098, doi:10.1029/2001GB001849, 2002.

Horner, R. A. and G. C. Schrader.: Relative contributions of ice algae, phytoplankton and benthic microalgae to primary production in nearshore regions of the Beaufort Sea, Arctic, 35, 485503, 1982 .
Horspool W. and Armesto D.: Organic Photochemistry: A Comprehensive Treatment, Ellis Horwood, Chichester, UK, 1-521, 1992.

Hurst, J. R., Wilson, S. L., and Schuster, G. B.: The ene reaction of singlet oxygen: kinetic and product evidence in support of a perepoxide intermediate, Tetrahedron, 41, 2191-2197, 1985.

Ingalls, A. E., Lee, C., Wakeham, S. G., and Hedges, J. I.: The role of biominerals in the sinking flux and preservation of amino acids in the Southern Ocean along $170^{\circ} \mathrm{W}$, Deep-Sea Res. Pt. II, 50, 713-738, 2003.

Ishida, Y.: Thirty years of research on dimethylsulfoniopropionate, in: Biological and Environmental Chemistry of DMSP and Related Sulfonium Compounds, edited by: Kiene, R. P., Vissher, P. T., Keller, M. D., and Kirst, G. O., Plenum Press, New York, 1-12, 1996.

Katsev, S., Sundby, B., and Mucci, A.: Modeling vertical migrations of the redox boundary in sediments: Application to deep basins of the Arctic Ocean, Limnol. Oceanogr., 51, 1581-1593, 2006.

Keller, M. D., Bellows, W. K., and Guillard, R. R. L.: Dimethyl sulfide production in marine phytoplankton, in: Biogenic Sulfur in the Environment, 194th Meeting of the American Chemical Society, New Orleans, Louisiana, 167-182, 1989.

Keweloh, H. and Heipieper, H. J.: Trans-unsaturated fatty acids in bacteria, Lipids, 31, 129-137, 1996.

Kiene, R. P. and Visscher, P. T.: Production and fate of methylated sulfur compounds from methionine and dimethylsulfoniopropionate in salt march sediments, Appl. Environ. Microbiol., 53, 2426-2434, 1987.

Kolattukudy, P. E.: Chemistry and Biochemistry of Natural Waxes, Elsevier, New York, 1976.

Korytowski, W., Bachowski, G. J., and Girotti, A. W.: Photoperoxidation of cholesterol in homogeneous solution, isolated membranes, and cells: comparison of the $5 \alpha$ - and $6 \beta$-hydroperoxides as indicators of singlet oxygen intermediacy, Photochem. Photobiol., 56, 1-8, 1992.

Link, H., Chaillou, G., Piepenburg, D., and Archambault, P.: Effect of abiotic environment on the biogeochemical response of Arctic sediment, Biogeoscience, in preparation, 2012.

Lomans, B. P., van der Drift, C., Pol, A., and Op den Camp, H. J. M.: Microbial cycling of volatile organic sulfur compounds, Cell. Mol. Life Sci., 59, 575-588, 2002.

Macdonald, R. W. and Yu, Y.: The Mackenzie estuary of the arctic ocean, in: The Handbook of Environmental Chemistry, edited by: Wangersky, P. J., Springer, Berlin, 91-120, 2006.

Macdonald, R. W., Solomon, S. M., Cranston, R. E., Welch, H. E., Yunker, M. B., and Gobeil, C.: A sediment and organic carbon budget for the Canadian Beaufort Shelf, Mar. Geol., 144, 255273, 1998.

McGuire, A. D., Anderson, L. G., Christensen, T. R., Dallimore, S., Guo, L. D., Hayes, D. J., Heimann, M., Lorenson, T. D., Macdonald, R. W., and Roulet, N.: Sensitivity of the carbon cycle in the Arctic to climate change, Ecol. Monogr., 79, 523-555, 2009.

Magen, C.: Origin, sedimentation and diagenesis of organic matter in coastal sediments of the southern Beaufort Sea region, Canadian Arctic, Ph.D., MacGill university, 2007.

Magen, C., Chaillou, G., Crowe, S. A., Mucci, A., Sundby, B., Gao, A. G., Makabe, R., and Sasaki, H.: Origin and fate of particulate organic matter in the southern Beaufort Sea - Amundsen Gulf region, Canadian Arctic, Estuar. Coast. Shelf Sci., 86, 31-41, 2010. 
Marchand, D. and Rontani, J.-F.: Characterization of photooxidation and autoxidation products of phytoplanktonic monounsaturated fatty acids in marine particulate matter and recent sediments, Org. Geochem., 32, 287-304, 2001.

Marchand, D. and Rontani, J.-F.: Visible light-induced oxidation of lipid components of purple sulphur bacteria: A significant process in microbial mats, Org. Geochem., 34, 61-79, 2003.

Marchand, D., Marty, J.-C., Miquel, J.-C., and Rontani, J.-F.: Lipids and their oxidation products as biomarkers for carbon cycling in the northwestern Mediterranean Sea: results from a sediment trap study, Mar. Chem., 95, 129-147, 2005.

Milliman, J. D. and Meade, R. H.: World-wide delivery of river sediment to the oceans, J. Geol., 91, 1-21, 1983.

Morrissey, P. A. and Kiely, M.: Oxysterols: Formation and biological function, in: Advanced Dairy Chemistry 3rd edition, edited by: Fox, P. F. and McSweeney, P. L. H., Springer, New York, Lipids, 2, 641-674, 2006.

Navarrete, A., Peacock, A., Macnaughton, S. J., Urmeneta, J., MasCastellà, J., White, D. C., and Guerrero, R.: Physiological status and community composition of microbial mats of the Ebro Delta, Spain, by signature lipid biomarkers, Microb. Ecol., 39, 92-99, 2000.

Niggemann, J., Ferdelman, T. G., Lomstein, B. A., Kallmeyer, J., and Schubert, C. J.: How depositional conditions control input, composition, and degradation of organic matter in sediments from the Chilean coastal upwelling region, Geochim. Cosmochim. Ac., 71, 1513-1527, 2007.

O’Brien, M. C., Macdonald, R. W., Melling, H., and Iseki, K.: Particle fluxes and geochemistry on the Canadian Beaufort Shelf: implications for sediment transport and deposition, Cont. Shelf Res., 26, 41-81, 2006.

Porter, N. A., Caldwell, S. E., and Mills, K. A.: Mechanisms of free radical oxidation of unsaturated lipids, Lipids, 30, 277-290, 1995.

Rachold, V., Grigoriev, M. N., Are, F. E., Solomon, S., Reimnitz, E., Kassens, H., and Antonow, M.: Coastal Erosion vs. Riverine Sediment Discharge in the Arctic Shelf Seas, Int. J. Earth Sci., 89, 450-460, 2000.

Rachold, V., Eicken, H., Gordeev, V. V., Grigoriev, M. N., Hubberten, H. W., Lisitzin, A. P., Shevchenko, V. P., and Schirrmeister, L.: Modern terrigenous organic carbon input to the Arctic Ocean, in: The Organic Carbon Cycle in the Arctic Ocean, edited by: Stein, R. S. and Macdonald, R. W., Springer, New York, 33 55, 2004.

Richerol, T., Rochon, A., Blasco, S., and Scott, D.: Evolution of paleo sea-surface conditions over the last 600 years in the Mackenzie Trough, Beaufort Sea (Canada), Mar. Micropaleontol., 68, 620, 2008.

Rontani, J.-F. and Marchand, D.: $\Delta^{5}$-Stenol photoproducts of phytoplanktonic origin: a potential source of hydroperoxides in marine sediments?, Org. Geochem., 31, 169-180, 2000.

Rontani, J.-F., Cuny, P., and Grossi, V.: Identification of a pool of lipid photoproducts in senescent phytoplanktonic cells, Org. Geochem., 29, 1215-1225, 1998.

Rontani, J.-F., Koblizek, M., Beker, B., Bonin, P., and Kolber, Z.: On the origin of $c i s$-vaccenic photodegradation products in the marine environment, Lipids, 38, 1085-1092, 2003.

Rontani, J.-F., Bonin, P., Prahl, F. G., Jameson, I., and Volkman, J. K.: Experimental and field evidence for thiyl radical-induced stereomutation of alkenones and other lipids in sediments and seawater, Org. Geochem., 37, 1489-1504, 2006.

Rontani, J.-F., Zabeti, N., and Wakeham, S. G.: The fate of marine lipids: Biotic vs. abiotic degradation of particulate sterols and alkenones in the Northwestern Mediterranean Sea, Mar. Chem. 113, 9-18, 2009.

Rontani, J.-F., Zabeti, N., and Wakeham, S. G.: Degradation of particulate organic matter in the equatorial Pacific Ocean: biotic or abiotic?, Limnol. Oceanogr., 56, 333-349, 2011.

Rontani, J.-F., Charriere, B., Sempéré, R., Doxaran, D., Vaultier, F., and Volkman, J. K.: Lipid biomarker evidence for extensive biotic and abiotic degradation of terrestrial organic matter in Arctic coastal waters, Geochim. Cosmochim. Ac., in review, 2012a.

Rontani, J.-F., Charriere, B., Forest, A., Heussner, S., Vaultier, F., Petit, M., Delsaut, N., Fortier, L., and Sempéré, R.: Intense photooxidative degradation of planktonic and bacterial lipids in sinking particles collected with sediment traps across the Canadian Beaufort Shelf (Arctic Ocean), Biogeosciences Discuss., 9, 7743-7781, doi:10.5194/bgd-9-7743-2012, 2012b.

Ruettinger, R. T. and Fulco, A. J.: Epoxidation of unsaturated fatty acids by a soluble cytochrome P-450-dependent system from Bacillus megaterium, J. Biol. Chem., 256, 5728-5734, 1981.

Schaich, K. M.: Lipid oxidation: theoretical aspects, in: Bailey's Industrial Oil and Fat Products, Sixth edition, edited by: Shahidi, F., John Wiley \& Sons, 269-355, 2005.

Scott, D., Schell, T., St-Onge, G., and Rochon, A.: Foraminiferal assemblage changes over the last 15,000 years on the Mackenzie-Beaufort sea slope and Amundsen Gulf, Canada: Implications for past sea-ice, Paleoceanogr., 24, 1-20 doi:10.1029/2007PA001575, 2009.

Sicre, M.-A., Paillasseur, J. L., Marty, J.-C., and Saliot, A.: Characterization of seawater samples using chemometric methods applied to biomarker fatty acids, Org. Geochem., 12, 281-288, 1988.

Smith, L. L.: The Autoxidation of Cholesterol, Plenum Press, New York, 119-132, 1981.

Stein, R. and Macdonald, R. W.: The Organic Carbon Cycle in the Arctic Ocean, Springer, Berlin, 363 pp., 2004.

Testa, A. C.: Photosensitized cis-trans isomerization of Methyl Oleate, J. Org. Chem., 29, 2461-2462, 1964.

Unger, D., Gaye-haake, B., Neumann, K., Gebhardt, A. C., and Ittekkot, V.: Biogeochemistry of suspended and sedimentary material in the $\mathrm{Ob}$ and Yenisei rivers and Kara Sea; amino acids and amino sugars, Cont. Shelf Res., 25, 437-460, 2005 a.

Unger, D., Ittekkot, V., Schafer, P., and Tieman, J.: Biogeochemistry of particulate organic matter from the Bay of Bengal as discernible from hydrolysable neutral carbohydrates and amino acids, Mar. Chem., 96, 155-184, 2005 b.

Van Dongen, B. E., Zencak, Z., and Gustafsson, O.: Differential transport and degradation of bulk organic carbon and specific terrestrial biomarkers in the surface waters of a sub-arctic brackish bay mixing zone, Mar. Chem., 112, 203-214, 2008.

Volkman, J. K.: A review of sterol markers for marine and terrigenous organic matter, Org. Geochem., 9, 83-99, 1986.

Volkman, J. K.: Sterols in microorganisms, Appl. Microbiol. Biotechnol., 60, 495-506, 2003.

Vonk, J. E., van Dongen, B. E., and Gustafsson, O.: Lipid biomarker investigation of the origin and diagenetic state of sub-arctic terrestrial organic matter presently exported into the northern Both- 
nian Bay, Mar. Chem., 112, 1-10, 2008.

Wakeham, S. G.: Reduction of stenols to stanols in particulate matter at oxic-anoxic boundaries in seawater, Nature, 342, 787-790, 1989.

Wakeham, S. G. and Lee, C.: Organic geochemistry of particulate matter in the ocean: The role of particles in oceanic sedimentary cycles, Org. Geochem., 14, 83-96, 1989.

Wakeham, S. G. and Canuel, E. A.: Lipid composition of the pelagic crab Pleuroncodes planipes, its feces, and sinking particulate matter in the equatorial North Pacific Ocean, Org. Geochem., 9, 331-343, 2006.

White, D. C., Stair, J. O., and Ringelberg, D. B.: Quantitative comparisons of in situ microbial diversity by signature biomarker analysis, J. Ind. Microbiol., 17, 185-196, 1996.
Wlodek, L.: Beneficial and harmful effects of thiols, Polish J. Pharmacol., 54, 215-223, 2002.

Yoch, D. C.: Dimethylsulfoniopropionate: its sources, role in the marine food web, and biological degradation to dimethylsulfide, Appl. Environ. Microbiol., 68, 5804-5815, 2002.

Yunker, M. B., Macdonald, R. W., Veltkamp, D. J., and Cretney, W. J.: Terrestrial and marine biomarkers in a seasonally icecovered Arctic estuary: Integration of multivariate and biomarker approaches, Mar. Chem., 49, 1-50, 1995.

Yunker, M. B., Belicka, L. L., Harvey, H. R., and Macdonald, R. W.: Tracing the inputs and fate of marine and terrigenous organic matter in Arctic Ocean sediments: A multivariate analysis of lipid biomarkers, Deep-Sea Res., 52, 3478-3508, 2005. 